\title{
Experimental and numerical investigation of footing behaviour on
}

\section{multi-layered rubber-reinforced soil}

\author{
S.N. Moghaddas Tafreshi ${ }^{1, *}$ (Corresponding Author), N. Joz Darabi ${ }^{2}$, Gh. Tavakoli Mehrjardi ${ }^{3}$, A. R. \\ Dawson $^{4}$ \\ 1,* Corresponding Author, Professor, Department of Civil Engineering, K.N. Toosi University of Technology, Valiasr St., \\ Mirdamad Cr., Tehran, Iran. Tel: +982188779473; Fax: +982188779476; E-mail address: nas moghaddas@ kntu.ac.ir \\ ${ }^{2}$ Department of Civil Engineering, PhD Candidate, K.N. Toosi University of Technology, Tehran, Iran. Tel: \\ +982188779473; Fax: +982188779476; Email:ndarabi@mail.kntu.ac.ir \\ ${ }^{3}$ Assistant Professor, Department of Civil Engineering, Kharazmi University, Hesarak, Iran. Tel: +989127909295; E-mail \\ address: ghtavakoli@khu.ac.ir \\ ${ }^{4}$ Associate Professor, Nottingham Transportation Engineering Centre, University of Nottingham, Nottingham, UK. Tel: \\ +441159513902; Fax: +441159513909; E-mail address: andrew.dawson@ nottingham.ac.uk
}

Abstract: This paper describes the beneficial effects of multiple layers of rubber-sand mixture (RSM). The plate load tests, using circular plate of $300 \mathrm{~mm}$ diameter, were performed at an outdoor test pit, dug in natural ground with dimensions of $2000 \times 2000 \mathrm{~mm}$ in plan and $720 \mathrm{~mm}$ in depth to facilitate realistic test conditions. The rubber used in the RSM layers was granulated rubber, produced from waste tires. The optimum thickness of the RSM layer was determined to be approximately 0.4 times the footing diameter. By increasing the number of RSM layers, the bearing capacity of the foundation can be increased and the footing settlement reduced. The influence of the number of RSM layers on bearing capacity and settlement become almost insignificant beyond three layers of RSM, particularly at low settlement ratios. At a ratio of settlement to plate diameter of $4 \%$, the values of bearing pressure for the installation with one, two, three and four layers of RSM were about 1.26 , 1.47, 1.52 and 1.54 times greater, respectively, than that for the unreinforced installation. Layers of the RSM reduced the vertical stress transferred through the foundation depth by distributing the load over a wider area. For example, at an applied footing pressure of $560 \mathrm{kPa}$, the transferred pressure at a depth of $570 \mathrm{~mm}$ were about $58 \%, 45 \%$ and $35 \%$ for one, two, and three layers of RSM, respectively, compared to the transferred stress in the unreinforced bed. By numerical analysis, it was found that the presence of soil-rubber layers resulted in expansion of passive zones in the foundation due to the effectiveness of the confinement provided by the rubber inclusions, and this tends to make the bed deflect less. On the basis of this study, the concept of using multiple RSM layers has not only been shown to improve the performance of foundations under heavy loading, but also, the environmental impacts of waste tires are attenuated by re-using their rubber as part of a composite soil material in civil engineering works.

Keywords: Multiple Rubber-soil mixture (RSM) layers, Plate load test, Bearing pressure, Numerical analysis. 


\section{Introduction}

In recent decades, the volume of scrap tire rubber in the world has increased significantly because of the globally developing vehicle industry and due to growing population (RRI, 2009; RMA, 2013). Consequently, their disposal has become a major environmental problem worldwide (Hennebert, 2014). Hundreds of millions of waste tires are either dumped in landfills or stockpiled, despoiling the environment (Cetin et al., 2012; Chiu, 2008). The increasing volumes mean that it is harder and more expensive to safely dispose them without threatening human health and environment. For instance, stockpiled waste tires are flammable, prone to fires that produce toxic fumes and which may then cause a major health hazard for both human beings and animals (Attom, 2006).

To address the environmental concerns, the use of waste tires in the form of fibers, strips, chips, granulated, crumbed or shredded, are now considered as construction materials (Zhou et al., 2002; Tanchaisawat et al., 2010; Moghaddas Tafreshi et al., 2012; Edincliler and Cagatay, 2012, 2013; Munnoli et al., 2013; Prasad et al., 2014; Keskin and Laman, 2014; Diambra and Ibraim, 2014; SolSánchez, 2015; Karabash and Cabalar, 2015; Moghaddas Tafreshi and Norouzi, 2015; Brara, 2016). Using waste tires combined with soil is becoming popular due to the shortage of natural mineral resources and the increasing waste disposal costs of tires. In addition, when the chipped, shredded and granulated tire rubbers are mixed with soil (or the strips of tire used as reinforcement), the mixture might behave as reinforced soil, similar to geosynthetic-reinforced soil, which can be advantageously employed to increase soil strength, depending on the rubber content and the size of rubber particles (Hataf and Rahimi, 2005; Yoon et al., 2006; Tavakoli Mehrjardi et al., 2012; Moghaddas Tafreshi and Norouzi, 2012; Edincliler and Cagatay, 2013, Bali Reddy et al., 2016).

Yoon et al. (2006) evaluated the feasibility of using tire shred-sand mixtures as a fill material in embankment construction. A test embankment was constructed using a 50/50 mixture, by volume of tire shreds and sand. They reported that, after 200 days of road traffic, the settlement stabilized at small values when compared with pure tire shreds and pure sand. Edincliler and Cagatay (2013) investigated the feasibility of reinforcing soil with extensible buffing rubber inclusions by observing the CBR performance of the mixtures. They reported that adding $5 \%$ of fiber-shaped buffing rubber by weight to 
sand formed a reinforced composition for use in geotechnical applications, improving the CBR value of soil. Moghaddas Tafreshi and Norouzi (2012), using a small scale test, found that the optimal thickness of a single layer of rubber-soil mixture was approximately 0.5 times the width of the footing to achieve the maximum improvement in bearing capacity of the foundation bed. They reported that an increase in the thickness of rubber-soil mixture beyond its optimum value increases the soil's compressibility because of an increase in the total void space between the soil particles of the mixture and increases the settlement of the foundation bed. Consequently, the reinforcing effect of the rubber-soil mixture is decreased with a probably undesirable effect on the foundation response.

Some researchers studied the behaviour of fiber-reinforced soil by computational methods. Babu et al. (2008) proposed an approach for considering the effect of random-oriented fibres in numerical analyses. The reinforcement mechanisms achieved by random fiber-reinforced sand are explained in terms of a microstructure that prevents the formation of distinct localized strain bands. Tavakoli Mehrjardi et al. (2015) studied the behaviour of pipes in a trench protected by geocell-reinforced sand and rubber-soil mixtures, under repeated loadings. The results demonstrated that combined use of the geocell layer and rubber-soil mixture can reduce soil surface settlement and pipe deflection and eventually provide a secure condition for buried pipes even under strong repeated loads.

Since one-layer rubber-soil mixtures with optimum thickness could be effective in improving the behavior of a foundation (Moghaddas Tafreshi and Norouzi, 2012), it seems likely that multi-layered rubber-soil mixture, used in the active zone beneath the footing - perhaps over a depth of 1-2 times the footing diameter - can improve the foundation response by reducing deformations. Consequently, this paper seeks to investigate the concept of the beneficial effect of multiple rubber-soil mixture layers constructed in the foundation, as might be used in roads, highways, embankments, footings, etc. The vertical spacing between successive layers is particularly considered.

In this paper the abbreviation "RSM" is used by the authors to describe "Rubber-Soil Mixture". Additionally, a numerical study, representative of the full-scale model test, is reported. This was undertaken to understand the behaviour of multi-layered rubber-reinforced foundations so as to propose 
empirical relationships of stress propagation through the unreinforced and reinforced foundation which were not easily achievable using results from the experimental model alone.

\section{Objectives}

The overall goal is to demonstrate the beneficial effects of multi-layered RSM with optimum of rubber content, optimum thickness of RSM layers and optimum vertical space between successive layers on the bearing capacity and settlement of foundation beds. Also, the effect of the RSM layers on the stress distribution and deformation profile with depth is investigated. The results consist of two parts including results of the plate load tests (Section 6.1) and of the 3-dimensional numerical modeling of the foundation bed (Section 6.2).

\section{Test Materials}

\subsection{Backfill soil}

A sandy soil passing through the $38 \mathrm{~mm}$ sieve with a specific gravity, $\mathrm{G}_{\mathrm{s}}$, of 2.62 was used as backfill for the unreinforced layers and also to mix with rubber for construction of the RSM layers. This type of soil was sourced from a local quarry and satisfies the criteria and limitations recommended in ASTM D 2940-09. The soil grading is presented graphically in Fig. 1. This soil is classified as well graded sand (SW) in the Unified Soil Classification System (ASTM D 2487-11). Modified proctor compaction tests were performed on the soil, according to ASTM D 1557-12. A summary of soil properties is presented as Table 1 .

\subsection{Rubber}

Granulated tire rubbers, clean and free of any steel and cord, were used in all the tests. The particles have a specific gravity, $\mathrm{G}_{\mathrm{s}}$, of 1.17 , major dimensions of between 2 and $25 \mathrm{~mm}$ and a mean particle size of $14 \mathrm{~mm}$. Figs. 1 and 2 show, respectively, the grading and a photograph of the rubber particles used in the tests. The rubbers particles were carefully blended with the soil, by a mixer and with manual intervention if necessary, so as to produce a reasonably uniform, non-segregated rubber-soil mixture.

\section{Test Setup}

Full-scale plate load tests, simulating small foundations, were performed to investigate the response of untreated soil and the soil-rubber mixture with respect to bearing capacity and settlement. The 
schematic cross-section of the test set-up, including the model test pit, layers of the backfill soil, RSM layers, the loading system, data acquisition systems (including dial gauges and soil pressure cells) and the geometry of the test configurations (including the parameter definitions), are shown in Fig. 3. The following sections present the essential details of the test setup.

\subsection{Test pit and instrumentation}

All plate load tests were conducted in an outdoor test pit (see Acknowledgements). The test pit, measuring $2000 \mathrm{~mm} \times 2000 \mathrm{~mm}$ in plan, and $720 \mathrm{~mm}$ in depth, was excavated in natural ground and into this were substituted the soil and RSM layers (Fig. 3).To measure the movement of the loading plate (footing model), throughout the tests, three linear dial gauges with an accuracy of $0.01 \%$ of full range $(100 \mathrm{~mm})$ were installed. Also, the foundation was instrumented with three full bridge, $50 \mathrm{~mm}$ diameter diaphragm-type soil pressure cells (abbreviated to SPC) to measure the transferred vertical stress inside the foundation. According to the manufacturer, these had an accuracy of $0.01 \%$ of full range of $1000 \mathrm{kPa}$. The top soil pressure cell (abbreviated to "SPC 1"), middle soil pressure cell (SPC 2") and bottom soil pressure cell ("SPC 3") are located, respectively, at depths of $210 \mathrm{~mm}, 390 \mathrm{~mm}$ and $570 \mathrm{~mm}$ beneath the center of loading plate (Fig. 3). The instruments' outputs were recorded in $\mathrm{mV}$ and then converted to real stress units using calibration factors supplied by the manufacturer.

\subsection{Backfill compaction}

In order to compact the layers of the foundation including soil and RSM layers, a walk-behind vibrating plate compactor, $450 \mathrm{~mm}$ in width, was used. To achieve the required density of backfill layers, the soil and RSM mixture layers were compacted at a thickness of $60 \mathrm{~mm}$ and at the optimum moisture content of 5.7\% with one and three passes of the compactor, respectively. In all, twenty layers required compaction. In order to try to keep the compaction effort, and consequently the compaction energy, constant the forward velocity of the compactor was kept constant. To better assess the layers' compaction, cone tests in accordance with ASTM D 1557-12 were performed in some installations, to check the densities and moisture contents of the compacted soil layers and RSM layers. The density values measured in the three cone tests revealed density differences $\leq 1.8 \%$. The average measured (recovered) moisture content of the layers was between 5.4\% and 5.8\%. To prevent loss of moisture 
from the backfill during the load test, the exposed backfill was covered by a waterproof paper. The average measured dry densities (average of three sand cone tests) of soil and RSM layers after compaction were about $16.52 \mathrm{kN} / \mathrm{m}^{3}$ (approximately $80 \%$ of maximum soil dry density), and 13.6 $\mathrm{kN} / \mathrm{m}^{3}$, respectively.

\subsection{Loading system}

The plate loading system was a hand-operated hydraulic jack, supported against a strong reaction beam spanning the width of the test pit, with the capability of applying a stepwise controlled load up to $50 \mathrm{kN}$. The diameter, $D$, and thickness of the loading plate were $300 \mathrm{~mm}$ and $25.4 \mathrm{~mm}$, respectively, according to ASTM D1196-04. The standard declares that the circular steel plate should be not less than $25.4 \mathrm{~mm}$ in thickness, having a diameter between 150 and $750 \mathrm{~mm}$. The steel rigid circular plate was placed at the centre of the ground surface. In all tests, the load was applied monotonically to the model footing at a rate of $1.5 \mathrm{kPa}$ per second until reaching $1000 \mathrm{kPa}$ or until backfill failure. In the absent of a clear-cut failure, the footing was loaded to reach a footing settlement of $75 \mathrm{~mm}(s / D=25 \%)$. Fig. 4 depicts a photograph of the test setup and operator.

\section{Test program}

To investigate the beneficial effect of RSM layers on the behaviour of foundation, three test series including one, two, three and four layers of RSM (Test Series 2, 3, and 4), as well as an unreinforced condition (Test Series 1) with monotonically increasing load, were conducted. Details of the tests configurations are given in Table 2. "Test Series 1" provided a control case to which the response of all other foundation arrangements could be referenced. The optimum value of rubber content in a rubbersoil mixture is obtained from the results of "Test Series 2" which used one layer of RSM with no soil cover $(u / D=0)$. In this Test Series, the rubber content $\left(R_{c}\right)$ in the rubber-soil mixture was varied between $4 \%$ and $16 \%$, by mass of the mixture, in $2 \%$ steps. "Test Series $3 "$ was performed to obtain the optimum value of the thickness of RSM layers $\left(h_{r s} / D\right)$ using one layer of RSM. The beneficial effect of number of multiple RSM layers $(N=1,2,3,4)$ was examined in Test Series 4.

Depth of the first layer of RSM beneath the loading plate $(u)$ in Test Series 3 and 4 and thickness of the soil layer between the mixture layers $(h)$ in Test Series 4 were selected to be $0.2 D$ (based on Yoon et 
al., (2008)). The width of the RSM layers $(b)$ is expressed in non-dimensional form $(b / D)$ with respect to loading plate diameter $(D=300 \mathrm{~mm})$. In line with the findings of Dash et al. (2003), Yoon et al. (2008) and Thakur et al. (2012) for 3D reinforcement (i.e. geocell and tire-cell), the parameter $b / D$ was kept constant in all the tests at $b / D=5$ on the basis that reinforcement and RSM layers beneath the footing might have, approximately, the same basic mechanisms of foundation reinforcement.

In order to assess the utility of the apparatus, the accuracy of the measurements, the repeatability of the system, the reliability of the results and finally to verify the consistency of the test data, many of the tests described in Table 2 were repeated at least twice. The results obtained revealed a close match between results of the two or three trial tests with maximum differences in results of around $4 \sim 7 \%$. This difference was considered to be small and is subsequently neglected. The consistency of the results demonstrates that the mixture of soil and rubber, the test procedure and the technique adopted can produce repeatable tests within the bounds that may be expected from geotechnical and pavement testing apparatuses.

In order to prevent damage of the soil pressure cells (SPC), they are installed only for Test Series 1 and 4 (i.e. for the foundation beds with one layer of RSM in Test Series 2 and 3, no pressure cells are installed).

\section{Results and discussion}

\subsection{Experimental results}

In this section, the results of plate load tests are presented along with a discussion, highlighting effects of the different parameters such as rubber content, number of RSM layer and its thickness. Here, the performance improvement of the foundation is represented by considering the bearing pressure, settlement and the pressure distribution down through the foundation.

\subsubsection{The effect of the rubber content $\left(R_{c}\right)$}

To investigate the effect of the rubber content on foundation performance, Test Series 2 was implemented, placing one layer of rubber-soil mixture, beneath the footing base (with no soil cover, $u / D=0)$. The thickness of the RSM layer, $h_{r s}$, was selected as $60 \mathrm{~mm}\left(h_{r s} / D=0.2\right)$. The variation of 
bearing pressure with rubber content at different values of settlement is depicted in Fig. 5. This figure reveals that rubber content is more effective in improving the footing bearing capacity at higher footing settlements. Also, the reinforcement effect achieved by adding the rubber is highly dependent on the rate of shear strain. From this figure, it can be concluded that there is an optimum rubber content, about $8 \%$, irrespective of the loading plate's settlement which delivers the maximum increase in the bearing capacity. This rubber content is in the middle of the range of 6-10\% as reported by Prasad and Prasada Raju (2009) and Munnoli et al (2013).

Increasing the rubber content more than $8 \%$ makes the system response much softer (as also reported by Prasad and Prasada Raju (2009) and Edincliler et al. (2012)), tending to increase the deformability of the foundation beyond the value for the unreinforced soil. This replacement of the soil grains by a compressible material, like rubber, changes the composite's behaviour from a soil-like behaviour towards a rubber-like behaviour (i.e. an increase in settlement and a reduction in bearing capacity).

\subsubsection{The effect of the thickness of RSM layer $\left(h_{r s} / D\right)$}

Fig. 6a shows the applied pressure-settlement response (Tests Series 1 and 3) of the foundation with as a function of the thickness of a RSM layer, $h_{r s} / D$, when the content of granulated rubber is $8 \%$ and the layer is placed at a depth of $0.2(u / D=0.2)$ beneath the footing. As can be seen, in all tests, no clear failure point is evident from the pressure-settlement behavior. It is clear that, regardless of the level of settlement, when increasing the thickness of the RSM layer, both stiffness and bearing pressure were considerably improved compared to the values measured on untreated soils.

To gain a better assessment of the RSM layer performance, the variation of bearing capacity with thickness of RSM layer $\left(h_{r s} / D\right)$ is plotted for different footing settlement ratios $(s / D=2 \%, 4 \%, 6 \%, 8 \%$, $10 \%$ and $12 \%$ ) in Fig. $6 \mathrm{~b}$. The maximum footing settlement equals $12 \%$ of footing diameter, a rather large value. However, the discussion in this paper concentrates on the behavior at more tolerable settlement ratio values (e.g. $s / D=4 \%$ ). From Fig. $6 \mathrm{~b}$ it can be seen that, with an increase in $h_{r s} / D$ ratio, the bearing capacity increases until, approximately, $h_{r s} / D=0.4$, after which its value decreases, irrespective of footing settlement ratio. For example, at a settlement ratio of $s / D=4 \%$, the bearing pressure increases by about $25 \%, 27 \%, 13 \%$ and $5 \%$ compared to that of the unreinforced bed, for RSM 
layer thickness ratios, $h_{r s} / D$, equal to $0.2,0.4,0.6$ and 0.8 , respectively. This example suggests that a foundation system with a RSM layer thickness of more than 0.8 times the footing diameter $\left(h_{r s} / D>0.8\right)$ probably experiences punching failure resulting in a significant reduction in bearing pressure value, even less than that of the unreinforced bed. An alternative explanation is that the large thicknesses of RSM will make the system response much softer (Moghaddas Tafreshi and Norouzi 2012, 2015), causing more deflection to occur, such that no reinforcement effect can be seen.

\subsubsection{The effect of the number of RSM layers $(N)$}

To investigate the effect of the number of RSM layers on the foundation response, three additional tests, including two, three and four layers of RSM, were conducted at the optimum thickness of $h_{r s} / D=0.4$. They were placed at $u / D=h / D=0.2$ (see Table 2, Test Series 4). Fig. 7a presents the response of the loading plate in unreinforced and reinforced conditions. It is clearly observed that, as the number of RSM layers increases (i.e. as the depth of the reinforced zone increases), both stiffness and bearing capacity at a specified settlement increased, substantially. Similarly, at any given bearing pressure, the value of the settlement decreases with increase in the number of RSM layers. These changes could be attributed to the internal confinement provided by RSM layers in the active zone beneath the footing base, which restricts lateral displacement of different layers and, hence, tends to increase the bearing capacity. The concept of confinement due to fibre reinforcement, which has been termed internal confinement', was explained by Yang (1974). In the present situation, the confinement effect may be attributed to the mobilized tensile strength of the rubber particles exploited by interaction between aggregate and rubber particles.

In order to make a direct comparison between the results for the unreinforced and multi-layered RSM beds, the bearing pressure values for different numbers of RSM layers, corresponding to the different settlement ratios, are plotted in Fig. $7 \mathrm{~b}$. It can be seen that as the number of RSM layers increases, the bearing pressure increases steadily, regardless of the settlement ratio. For instance, at a settlement ratio of $s / D=4 \%$, the bearing capacity values are $\approx 293,340,353$ and $358 \mathrm{kPa}$ for one, two, three and four layers of RSM - increases, respectively, in bearing capacity of about $26 \%, 47 \%, 52 \%$ and $54 \%$ over the unreinforced bed's bearing capacity of $232 \mathrm{kPa}$. This example shows that the rate of 
enhancement in load carrying capacity of the footing reduces with increase in number of RSM layers $(N)$ such that one can anticipate the improvement rates will become insignificant with any further increase in the number of RSM layers. The reason is that the significantly stressed zone beneath the footing is estimated to be about 1-2 times the footing diameter/width into which only two/three layers of RSM can be placed. Any RSM placed below this zone will then only deliver marginal improvement in the foundation's response.

\subsubsection{The pressure transferred in depth of foundation bed}

The variation of measured pressure inside the unreinforced and multi-layered RSM beds at the three levels of $210 \mathrm{~mm}$ (“SPC 1"), $390 \mathrm{~mm}$ (“SPC 2"), and $570 \mathrm{~mm}$ (“SPC 3") beneath the center of footing (see Fig. 3) is illustrated in Fig. 8. In this figure, the pressure values at applied surface pressures of 280 and $560 \mathrm{kPa}$ are plotted with dotted and solid lines, respectively. The significant reduction of pressure inside the foundation bed is easily observed. This reduction is irrespective of the number of RSM layers and of the magnitude of applied load. For example, for a foundation bed containing three layers of RSM $(N=3)$ at an applied pressure of $280 \mathrm{kPa}$, the pressure measured at depths of 210,390 and $570 \mathrm{~mm}$ are $176.6,42.7$ and $15.8 \mathrm{kPa}$, respectively.

The pressure measured by the top soil pressure cell ("SPC 1"), at a depth of $210 \mathrm{~mm}$, is only affected by the first layer of RSM $(N=1)$. The presence or absence of the second or third layer RSM has no significant effect on its reading. Similarly, the pressures measured by the middle and bottom soil pressure cells ("SPC 2 and "SPC 3") are affected, respectively, only by the first two layers $(N=1,2)$ and only by the first three layers $(N=1,2,3)$. Thus, the stress at any depth is only affected by the construction above it and never by that below.

Fig. 8 also shows that the proportion of the applied surface pressure transferred down to a depth of $570 \mathrm{~mm}$ beneath the centre of footing base, as measured by the bottom soil pressure cell ("SPC 3"), considerably decreases relative to the unreinforced bed. It appears that an increase in the number of RSM layers improves the foundation's ability to spread load, regardless of the level of applied load (Tavakoli Mehrjardi et al., 2015). For example, at an applied pressure of $560 \mathrm{kPa}$, the vertical stress at a depth of $570 \mathrm{~mm}$ was $149.3,87.5,67.1$ and $52.2 \mathrm{kPa}$ for the unreinforced bed, and RSM beds with one, 
two and three layers of RSM, respectively. It also appears that the in-soil stress increases non-linearly with increase in the applied surface stress.

Taken together, the results presented in Figs. 5 to 8 reveal that use of RSM layers in a foundation reduces in-soil stresses and restricts vertical displacements. Insufficient data is available to categorically determine the mechanism by which this is achieved, but the response is consistent with the mechanism, known as the "confinement effect" in literature of soil reinforcement (Yang, 1974). This mechanism occurs when a reinforced layer acts like a large mat, spreading an applied load over an extended area, instead of directly at the point of contact. It provides a composite soil/reinforcement slab with higher flexural stiffness (Dash et al., 2003, Thakur et al., 2012), higher modulus, and load support capabilities within the zone that is significantly stressed by the foundation loading - consequently decreasing the magnitude of the distributed pressure on the vertical axis beneath the foundation.

\subsection{Numerical Analysis}

The numerical simulations for the analysis of multi-layered rubber-reinforced foundation were performed using the finite difference code FLAC-3D (2002). The geometry of the model, its calibration, its verification and a parametric study are discussed in the following sections.

\subsubsection{Model Geometry}

To calibrate and verify the multi-layered soil-rubber system, two different geometries were used. A cylindrical pattern was used to simulate the triaxial test in a calibration stage. Thereafter, the obtained material properties were applied to a numerical model representing the experimental model (see Fig. 3). Fig. 9 shows the meshing area of numerical model (in this example for a bed with three layers of RSM). The domain was divided into 17200 elements and 19866 grid points. The displacement of the outer boundary was restrained only in the direction at $90^{\circ}$ to the boundary while that of the base was restricted in all directions.

\subsubsection{Model Calibration}

As part of the calibration, several triaxial tests were performed to assess the properties of the unreinforced and rubber-reinforced soil layers. The soil, rubber material and the density of the unreinforced and rubber-reinforced soil used in the plate loading tests were replicated in the triaxial 
tests. Six triaxial tests on unreinforced and rubber reinforced soil samples with $8 \%$ rubber (as optimal rubber content), at three confining pressures of 50, 100 and $150 \mathrm{kPa}$ were conducted. The triaxial samples had a diameter of $100 \mathrm{~mm}$ and a height of $200 \mathrm{~mm}$. An elastic-perfectly plastic associative Mohr-Coulomb constitutive model was used to simulate the observed behaviour of unreinforced and rubber-reinforced layers. Even though more sophisticated elasto-plastic constitutive models exist, the Mohr-Coulomb model was deemed satisfactory in the present case as the anticipated stress paths are mainly dominated by shear failure when significant load is applied to the soil. To calibrate the parameters of the chosen plasticity model, the following points were considered:

a) Gotteland et al. (2005) investigated some triaxial tests on rubber-soil mixture and found that, with an increasing proportion of rubber volume in samples, the trend of most specimens was to yield a decrease of both cohesion and friction angle.

b) The dilation angle of all composites was assumed to be two-third of the value of friction angle in the corresponding composite material as suggested by Alimardani Lavasan and Ghazavi (2008).

To obtain the appropriate parameters, the numerical model was used to replicate the triaxial tests on the unreinforced and rubber-reinforced samples. By using a trial-and-error technique, adjusting the input parameters until the results of the numerical analysis closely matched those obtained from the triaxial tests, representative values of bulk modulus $(\mathrm{K})$, shear modulus $(\mathrm{G})$, cohesion $(\mathrm{c})$, friction angle $(\varphi)$, dilation angle $(\psi)$ and density $(\rho)$, were obtained. Fig. 10 compares the stress-strain responses of unreinforced and rubber-reinforced samples obtained from the calibration of numerical simulations and the experimental data measured from the same test configurations. As can be seen, there is, generally, a favorable match between the numerical results and the triaxial tests for both backfills. The soil properties (unreinforced and with $8 \%$ rubber inclusions by weight), as adopted for the numerical analysis of the unreinforced and multi-layered rubber-reinforced foundations, are presented in Table 3.

\subsubsection{Model Verification}

After calibration, models (incorporating the materials with the characteristics presented in Table 3 were used to simulate the unreinforced and multi-layered rubber-soil foundations. The loading was applied at a constant, low, rate of $1.5 \mathrm{kPa}$ per second in the vertical direction to simulate the non- 
dynamic, monotonically applied, plate loading process. Fig. 11 illustrates a small part of results at this stage of the study, comparing the pressure-settlement of the unreinforced bed and of the multiple-layer reinforced beds, as obtained from numerical analysis and from the experimental tests. A relatively good match can be observed between the numerical and experimental results. Fig. 12 is presented to compare pressure through the depth of the foundation beds, at applied pressures of 280 and $560 \mathrm{kPa}$, obtained from the numerical and experimental results for both unreinforced and reinforced beds. Clearly, the numerical model is able to simulate the physical tests results with a high accuracy and, therefore, provides a reliable means of performing analyses additional to those performed experimentally.

To help assess the stress and deformation distribution across the depth of the foundation bed, Figs. 13 and 14 illustrate the results of an applied pressure of $560 \mathrm{kPa}$. Fig. 14 shows that the presence of soil-rubber layers resulted in heaving around the footing. This may be because of expansion of the passive zones in the reinforced foundation due to the effectiveness of the confinement provided by rubber inclusions. In the unreinforced condition, part of the passive zone provided by the backfill has been lost, resulting in a reduction in bearing capacity compared with that of the reinforced bed (see Fig. 7(a)). This can be expected to make the bed deflect more. Tavakoli Mehrjardi et al. (2016) observed that the failure zones in a reinforced slope formed after a greater volume than in an unreinforced slope which might increase the likelihood that confinement be increased by the reinforcement.

As can be seen from Fig. 15, the intensity of shear strains beneath the footing has been reduced by using soil-rubber layers in the foundation. This might be due to reduction in surface soil settlements, leading to an attenuation of the the observed shear strains beneath the footing. Also, it can be concluded that the failure mechanism has been changed from shear punching to global shear failure by reinforcing the foundation and having an increased number of reinforcement layers. Ebrahimian and Nourzad (2013) similarly concluded that, in triaxial tests, large shear deformations were associated with a narrow band at the middle of the sample's layer, where failure may start.

To gain a better assessment of the stress distribution within both the unreinforced and RSM beds, Fig. 16 was presented. This figure shows the vertical stress distribution on horizontal planes at depths of 
$60,210,390$ and $570 \mathrm{~mm}$ from the ground surface, respectively. The applied surface pressure in all cases remained $560 \mathrm{kPa}$. Regardless of the number of RSM layers, the variation of vertical stress on a specified plane formed a ring-shaped stress distribution with its maximum on the centerline of loading, reducing with radial distance. For example, for a foundation bed containing three layers of RSM $(N=3)$, the pressure measured at the centerline of the loading surface and at depths of $60,210,390$ and $570 \mathrm{~mm}$ were about 553, 355, 158 and $98 \mathrm{kPa}$, respectively. Pancar and Akpinar (2012) by using some pressure cells in a foundation, also found out that the stress distribution was ring-shaped, having its maximum on the centerline.

Table 4 shows the stress distribution angle (the angle of the stress shadow to the vertical), calculated from Fig. 16, for each sort of foundation. Although, the stress spread in different sorts of reinforced foundations are similar, but it shows that the RSM system can reduce the vertical stress at depth by increasing the stress distribution angle. In respect of the stress distribution angle presented in Table 4, the stress can be considered to be distributed over a circular area with a diameter estimated by Eq. (1).

$D_{d}=D+n h_{s}$

Where,

$D_{d}$ : assumed equivalent diameter of stress distribution area at a specified depth of foundation

$D$ : Footing diameter

$h_{s}:$ specified depth of the foundation

$n$ : load spreading factor which $\approx 1.92,1.98,2.24$ and 2.27 for unreinforced foundation, $\mathrm{RSM}(\mathrm{N}=1)$, RSM (N=2) and RSM (N=3) respectively. In the line with the presented findings, Tavakoli Mehrjardi et al. (2015) proposed a load spreading factor of $n=1.5$ for unreinforced backfill.

\section{Conclusion}

A series of circular plate load tests were conducted to assess the ability of rubber-soil mixture (RSM) layers to provide potential foundation improvement. Benefits were assessed in terms of increased bearing capacity, decreased settlement of footings and reduced pressure profile. Based on the results described, the following conclusions can be made:

(1) The optimum percentage of waste tire rubber is around $8 \%$ of weight of the mixture matrix. 
(2) The optimum thickness of RSM layer, to achieve the maximum improvement in bearing pressure and settlement of a footing, is approximately 0.4 times footing diameter.

(3) With increase in the number of RSM layers, the bearing pressure of the footing increases and the footing settlement decreases due, in part, to better load spreading of the composite system. The values of bearing pressure for the RSM beds with one, two, three and four layers of RSM, at a settlement ratio of $s / D=4 \%$, are about $1.26,1.47 .1 .52$, and 1.54 times greater, respectively, than for the reference, unreinforced bed. The rate of enhancement in load carrying capacity of the footing was reduced with increase in the number of RSM layers. Performance improvement became almost insignificant beyond three RSM layers, particularly at low settlement ratios.

(4) The inclusion of a RSM layer beneath the loading plate leads to a significant reduction in the vertical stress transferred down through the foundation bed by distributing the load over a wider area. However, adding further RSM layers gives substantially less additional load spreading benefit such that a $4^{\text {th }}$ layer is unlikely to give any additional benefit. For the pressure of $560 \mathrm{kPa}$ applied on the footing, the transferred pressure at the depth of $570 \mathrm{~mm}$ are about $58 \%, 45 \%$ and $35 \%$ for the RSM bed with one, two, and three layers of RSM, respectively, compared to the pressure in the unreinforced bed.

(5) The pressure transferred to a given depth in the foundation bed varies non-linearly with applied pressure on the footing surface. For the foundation bed with two layers of RSM, the pressure values at the level of $390 \mathrm{~mm}$ beneath the center of footing grew by a factor of 2.35 when the level of the applied pressure only doubled.

(6) Numerical analysis shows that the presence of soil-rubber layers resulted in expansion of the passive zones due to the effectiveness of the confinement provided by the rubber inclusions and that this tends to make the bed deflect less. In addition, the RSM system reduces the vertical stress at any particular depth by increasing the effective stress distribution angle.

Generally, the results of this study provide considerable encouragement for the application of multiple layers of RSM (with optimum rubber content $\left(R_{c}\right)$, optimum thickness of RSM layers $\left(h_{r s} / D\right)$, optimum embedded depth of the first layer of RSM $(u / D)$ and optimum thickness of the soil layer 
between the RSM layers $(h / D))$ for filed-scale footings. However, the tests results are obtained for only one type of soil, one type and size of rubber and one size of footing diameter. Thus, specific applications using the quantitative results should only be made after considering these limitations. In studies on large- and small-scale tests of the behaviour of granular soil reinforced by planar reinforcement, Adams and Collin (1997) and Milligan et al. (1986) showed that the general mechanisms and behaviour observed in the small tests could be reproduced at large-scale. Therefore, insights into the basic mechanism of a foundation bed protected by RSM layers may be used to guide further studies on larger scale tests and centrifugal model tests. However, the results will aid planning of tests using different types and sizes of rubber, different sizes and shapes of footing, and different types and sizes of soil could be useful for future study. Also, the numerical studies have increased understanding of behaviour and will aid the development of design guidance in the application of multi-layered RSM. To gain a better understanding of the system, the rubber particles between the soil particles should be simulated more realistically or a more compatible constitutive model of the rubber-soil mixture should be developed, in any future study.

\section{Acknowledgments}

Dr. T. Amirsoleymani, the managing director of Mandro Consulting Engineers in Iran and their technicians provided the loading system and the instrumentation and provided great assistance during the tests. The authors appreciate all the above support.

\section{References}

Adams, M.T. Collin, J.G. (1997), "Large model spread footing load tests on geosynthetic reinforced soil foundations", Geotechnical and Geoenvironmental Engineering, 123 (1), 66-72.

Alimardani Lavason, A., Ghazavi, M., (2008). Influence of Interference on Failure Mechanism of Closely Constructed Circular Footings on Reinforced Sand. Proceedings of 4th Asian Regional Conference on Geosynthetcs, 311-317, Shanghai, China.

ASTM D422, Standard Test Method for Particle-Size Analysis of Soils. ASTM International, West Conshohocken, PA, USA. 
ASTM D1196 / D1196M, (2004), Standard Test Method for Nonrepetitive Static Plate Load Tests of Soils and Flexible Pavement Components, for Use in Evaluation and Design of Airport and Highway Pavements. ASTM International, West Conshohocken, PA, USA.

ASTM D1557, (2012), Standard Test Methods for Laboratory Compaction Characteristics of Soil Using Modified Effort. ASTM International, West Conshohocken, PA, USA.

ASTM D2487, (2011), Standard Practice for Classification of Soils for Engineering Purposes (Unified Soil Classification System). ASTM International, West Conshohocken, PA, USA.

ASTM D2940, (2009), "Standard Specification for Graded Aggregate Material for Bases or Subbases for Highways or Airports", ASTM International, West Conshohocken, PA, USA.

Attom, M.F. (2006), "The use of shredded waste tires to improve the geotechnical engineering properties of sands", Environmental and Geology, 49 (4), 497-503.

Babu GLS, Vasudevan AK, Haldar S. (2008), Numerical simulation of fiber-reinforced sand behaviour, Geotextiles and Geomembranes, 2008, Vol. 26, pp. 181-88.

Bali Reddy, S., Pradeep Kumar, D., Murali Krishna, A., 2016. Evaluation of the Optimum Mixing Ratio of a Sand-Tire Chips Mixture for Geoengineering Applications, Journal of Materialin Civil Eng., ASCE, 28 (2).

Brara, A., Brara, A., Daouadji, A., Bali, A., Daya, El. M., (2016). Dynamic properties of dense sand-rubber mixtures with small particles size ratio. European Journal of Environmental and Civil Engineering, 1-15

Cetin, B., Aydilek, A.H., Li, L., (2012). "Experimental and numerical analysis of metal leaching from fly ashamended highway bases", Waste Management, 32 (5), 965-978.

Chiu, C.T. (2008), "Use of ground tire rubber in asphalt pavements: field trial and Evaluation in Taiwan", Conservation and Recycling, 52 (3), 522-532.

Dash S.K., Sireesh S., Sitharam T.G. (2003), "Model studies on circular footing supported on geocell reinforced sand underlain by soft clay", Geotextiles and Geomembranes, 21 (4), 197-219.

Diambra, A., Ibraim, E. (2014), “Modelling of fibre-cohesive soil mixtures”, Acta Geotechnica, 9 (6), 1029-1043.

Ebrahimian B, Noorzad A (2013), "Numerical investigations of shear strain localization in an elasto-plastic Material" In Proceedings of 18th international conference on soil mechanics and geotechnical engineering, Paris,

France, pp 703-706. 
Edincliler, A., Cabalar, A.F., Cagatay, A., Cevik, A. (2012), "Triaxial compression behaviour of sand and tire wastes using neural networks", Neural Computing and Applications, 21, 441-452.

Edincliler, A., Cagatay, A. (2013), “Weak subgrade improvement with rubber fibre inclusions”, Geosynthetics International, 20 (1), 39-46.

FLAC-3D Fast Lagrangian Analysis of Continua in Threedimensions. ITASCA Consulting Group, Inc., Minneapolis, MN (2002).

Gotteland, P., Lambert, S., Balachowski, L. (2005), "Strength characteristics of tyre chips-sand mixtures", Studia Geotechnica et Mechanica, XXVII(1-2), 55-66.

Hataf, N., Rahimi, M.M. (2005) "Experimental investigation of bearing capacity of sand reinforced with randomly distributed tire shreds", Construction and Building Materials, 20 (10), 910-916.

Hennebert, P., Lambert, S., Fouillen, F., Charrasse, B. (2014). Assessing the environmental impact of shredded tires as embankment fill material. Canadian Geotechnical Journal. 51 (5), 469-478.

Karabash, Z., Cabalar, A. F. (2015). "Effect of tire crumb and cement addition on triaxial shear behavior of sandy soils”. Geomechanics and Engineering, An International Journal. 8(1), 1-15.

Keskin, M. S., Laman, M. (2014). "Experimental study of bearing capacity of strip footing on sand slope reinforced with tire chips", Geomechanics and Engineering, An International Journal. 6(3), 249-262.

Milligan, G.W.E., Fannin, R.J., Farrar, D.M. (1986), "Model and full-scale tests of granular layers reinforced with a geogrid", Proceedings of Third International Conference on Geotextiles, Vol. 1. Vienna, pp. 61-66.

Moghaddas Tafreshi, S. N., Tavakoli Mehrjardi, Gh. and Dawson, A. R. (2012). "Buried Pipes in Rubber-Soil Backfilled Trenches under Cyclic Loading”, ASCE, Journal of Geotechnical and Geoenvironmental Eng., 138(11), pp. 1346-1356.

Moghaddas Tafreshi, S.N., Norouzi, A.H. (2012) "Bearing capacity of a square model footing on sand reinforced with shredded tire-An experimental investigation”, Construction and Building Materials, 35, No.2012, 547-556.

Moghaddas Tafreshi, S.N., Norouzi, A.H. (2015). “Application of waste rubber to reduce the settlement of road embankment”, Geomechanics and Engineering, An International Journal. 9(2), 219-241.

Munnoli, P.M., Sheikh, S., Mir, T., Kesavan, V., Jha, R. (2013), "Utilization of rubber tyre waste in subgrade soil”, Global Humanitarian Technology Conference, South Asia Satellite (GHTC-SAS), 330-333. 
Pancar, E.B., Akpinar, M.V. (2016). Comparison of Effects of Using Geosynthetics and Lime Stabilization to Increase Bearing Capacity of Unpaved Road Subgrade, Advances in Materials Science and Engineering, 1 8.

Prasad, D.S.V., Prasada Raju, G.V.R. (2009), Performance of waste tyre rubber on model flexible pavement. ARPN, Journal of Engineering and Applied Sciences 4 (6), 89-92.

Prasad, S.A., Ravichandran P.T., Annadurai, R., Kannan Rajkumar, P.R. (2014), "Study on Effect of Crumb Rubber on Behavior of Soil”, International Journal of Geomatics and Geosciences, 4 (3), 579-583.

Recycling Research Institute, RRI. <http://www.scraptirenews.com>; 2009.

Rubber Manufacturers Association, RMA. <http://www.rma.org>; 2013.

Sitharam, T.G., Sireesh, S. (2005) "Behavior of embedded footings supported on geogrid cell reinforced foundation beds", Geotechnical Testing Journal 28 (5), 452-463.

Sitharam, T.G., Sireesh, S., Dash, S.K. (2007), "Performance of surface footing on geocell-reinforced soft clay beds", Geotechnical and Geological Engineering, 25 (5), 509-524.

Sol-Sánchez, M., Thom, N.H., Moreno-Navarro, M.C., Airey G.D. (2015), “A study into the use of crumb rubber in railway ballast”, Construction and Building Materials. 75 (January), 19-24.

Tanchaisawat, T., Bergado, D.T., Voottipruex, P., Shehzad, K. (2010), "Interaction between geogrid reinforcement and tire chip-sand lightweight backfill", Geotextiles and Geomembranes, 28 (1), 119-127.

Tavakoli Mehrjardi, Gh., Moghaddas Tafreshi, S.N., Dawson, A.R. (2012), "Combined use of geocell reinforcement and rubber-soil mixtures to improve performance of buried pipes" Geotextiles and Geomembranes, 34 (October), 116-130.

Tavakoli Mehrjardi, Gh., Moghaddas Tafreshi, S. N. and Dawson, A. R. (2015), "Numerical analysis on Buried pipes protected by combination of geocell reinforcement and rubber-soil mixture”, International Journal of civil engineering (IJCE), 13 (2), Transaction B, 90-104.

Tavakoli Mehrjardi, Gh., Ghanbari, A., Mehdizadeh, H. (2016). "Experimental study on the behaviour of geogridreinforced slopes with respect to aggregate size" Geotextiles and Geomembranes, 44, 862-871.

Thakur, J.K., Han, J., Pokharel, S.K., Parsons, R.L. (2012) "Performance of geocell-reinforced recycled asphalt pavement (RAP) bases over weak subgrade under cyclic plate loading”, Geotextiles and Geomembranes, 35 (December), 14-24.

Yang, Z. (1974), "Strength and Deformation Characteristics of Reinforced Sand" Ph.d Thesis, University of California, Los Angeles, USA. 
Yoon, S., Prezzi, M., Siddiki N. Z., Kim B. (2006), “Construction of a test embankment using a sand-tire shred mixture as fill material", Waste Management 26, 1033-1044.

Yoon, Y. W., Heo, S. B., Kim, S. K. (2008), “Geotechnical performance of waste tires for soil reinforcement from chamber tests", Geotextiles and Geomembranes, 26 (1), 100-107.

Zhou, C, Yin, JH, Ming, J.P. (2002), "Bearing capacity and settlement of weak fly ash ground improved using lime - fly ash or stone columns", Canadian Geotechnical Journal, 39 (3), 585-596. 


\section{LIST OF SYMBOLS}

\section{Nomenclature}

$b \quad$ Width of the RSM layers

$c \quad$ Cohesion of soil

$C_{u} \quad$ Coefficient of uniformity

$C_{c} \quad$ Coefficient of curvature

$D \quad$ Loading plate diameter

$D_{d} \quad$ assumed equivalent diameter of stress distribution area in a specified depth of foundation

$D_{10} \quad$ Effective grain size $(\mathrm{mm})$

$D_{30} \quad$ Diameter through which $30 \%$ of the total soil mass is passing (mm)

$D_{60} \quad$ Diameter through which $60 \%$ of the total soil mass is passing (mm)

$G, \quad$ Shear modulus of soil

$G_{s} \quad$ Specific gravity of soil

$h \quad$ Vertical spacing of the RSM layers

$h_{r s} \quad$ Height of the rubber-soil mixture layers

$h_{s} \quad$ Specified depth of the foundation

$K \quad$ bulk modulus of soil

$N \quad$ Number of RSM layers

$n \quad$ Load spreading factor

$R_{c} \quad$ Rubber content

$s \quad$ Footing settlement

$u \quad$ Embedded depth of the first layer of RSM

$\rho \quad$ Soil density

$\psi \quad$ Dilation angle

$\varphi \quad$ Angle of frictional resistance of soil

RSM Rubber Soil Mixture 
SPC Soil pressure cell

SPC 1 Top Soil Pressure Cell

SPC 2 Middle Soil Pressure Cell

SPC 3 Bottom Soil Pressure Cell 
Table 1 The physical properties of backfill soil

\begin{tabular}{|c|c|}
\hline Description & $\begin{array}{c}\text { Backfill } \\
\text { soil }\end{array}$ \\
\hline Coefficient of uniformity, $\mathrm{C}_{\mathrm{u}}$ & 33.82 \\
\hline Coefficient of curvature, $\mathrm{C}_{\mathrm{c}}$ & 2.36 \\
\hline Effective grain size, $\mathrm{D}_{10}(\mathrm{~mm})$ & 0.17 \\
\hline $\mathrm{D}_{30}(\mathrm{~mm})$ & 1.52 \\
\hline $\mathrm{D}_{60}(\mathrm{~mm})$ & 5.75 \\
\hline Specify Gravity $\left(\mathrm{G}_{\mathrm{s}}\right)$ & 2.62 \\
\hline Maximum dry density $\left(\mathrm{kN} / \mathrm{m}^{3}\right)$ & 20.62 \\
\hline Optimum moisture content $(\%)$ & 5.7 \\
\hline Angle of frictional resistance,,$($ degree $)$ at wet & 38 \\
\hline
\end{tabular}

Table 2 Scheme of the static load tests for unreinforced beds and beds containing RSM layers

\begin{tabular}{|c|c|c|c|c|c|c|}
\hline \multirow{2}{*}{$\begin{array}{l}\text { Test } \\
\text { Series }\end{array}$} & \multirow{2}{*}{$\begin{array}{l}\text { Type of } \\
\text { foundation } \\
\text { bed }\end{array}$} & \multicolumn{3}{|c|}{ Values of parameters studied in tests } & \multirow[t]{2}{*}{ No. of Tests } & \multirow[t]{2}{*}{ Purpose of the tests } \\
\hline & & $N$ & $h_{r s} / D$ & $R_{c}(\%)$ & & \\
\hline $1 * *$ & Unreinforced & ---- & ---- & & $1+1 *$ & $\begin{array}{c}\text { To quantify the improvements in } \\
\text { Test Series } 1,2 \text { and } 3\end{array}$ \\
\hline 2 & Containing & 1 & 0.2 & $\begin{array}{r}4 \%, 6 \%, 8 \%, \\
10 \%, \\
12 \%, \\
14 \%, \\
16 \%\end{array}$ & $7+4^{*}$ & $\begin{array}{l}\text { To arrive at optimum value of } \\
\text { rubber content }(u / D=0)\end{array}$ \\
\hline 3 & RsIn layer(s) & 1 & $\begin{array}{c}0.2,0.4,0.6 \\
0.8\end{array}$ & $8 \%$ & $4+3 *$ & $\begin{array}{l}\text { To arrive at the optimum values o } \\
h_{r s} / D(u / D=0.2)\end{array}$ \\
\hline $4 * *$ & & $2,3,4$ & 0.4 & $8 \%$ & $3+3 *$ & $\begin{array}{l}\text { To determine the effect of numbe } \\
\text { of RSM layers }(u / D=h / D=0.2)\end{array}$ \\
\hline \multicolumn{7}{|c|}{$\begin{array}{l}\text { *The tests which were performed two or three times to verify the repeatability of the test data } \\
* * \text { The Tests Series which the soil pressure cells were installed. }\end{array}$} \\
\hline \multicolumn{7}{|c|}{$\begin{array}{l}\text { Parameters definitions (D: Loading plate diameter, } u: \text { Embedded depth of the first RSM layer, } h_{r s}: \text { Height of RSM } \\
\text { layers, } h: \text { Vertical spacing of the RSM layers, } R_{c}: \text { Rubber content, } N: \text { Number of RSM layers). }\end{array}$} \\
\hline
\end{tabular}

Table 3 Details of material properties used in the present study obtained from calibration (Triaxial test)

\begin{tabular}{|c|c|c|c|c|c|c|}
\hline Backfill & K (Mpa) & G (Mpa) & C (kPa) & $\phi($ Deg.) & $\psi(\mathbf{D e g}$.) & $\boldsymbol{\rho}\left(\mathbf{~ k N} / \mathbf{m}^{\mathbf{3}}\right)$ \\
\hline Unreinforced Soil & 9.7 & 3.9 & 6.5 & 34 & 7 & 1.62 \\
\hline Rubber Soil Mixture (RSM) $\left(\mathrm{R}_{\mathrm{c}}=8 \%\right)$ & 6.3 & 3 & 20 & 34 & 5 & 1.45 \\
\hline
\end{tabular}

Table 4 Stress distribution angle for each sort of foundation

\begin{tabular}{|l|c|l|l|l|}
\hline Foundation Condition & Unreinforced & RSM (N=1) & RSM (N=2) & RSM (N=3) \\
\hline Stress distribution angle (Deg. & 43.8 & 44.7 & 47.2 & 48.4 \\
\hline
\end{tabular}




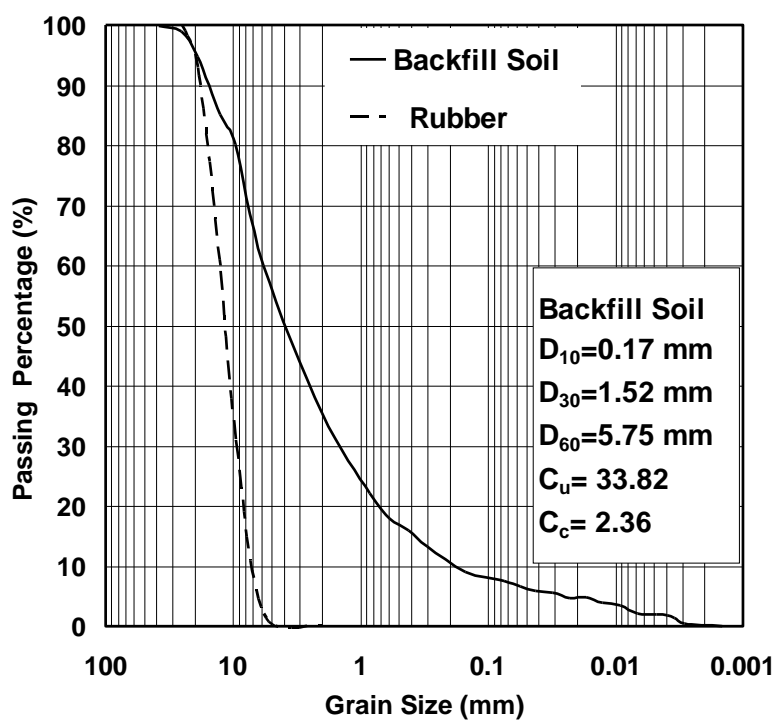

Fig. 1 Particle size distribution curves for backfill soil and granulated rubber (determined according to ASTM D422-07)

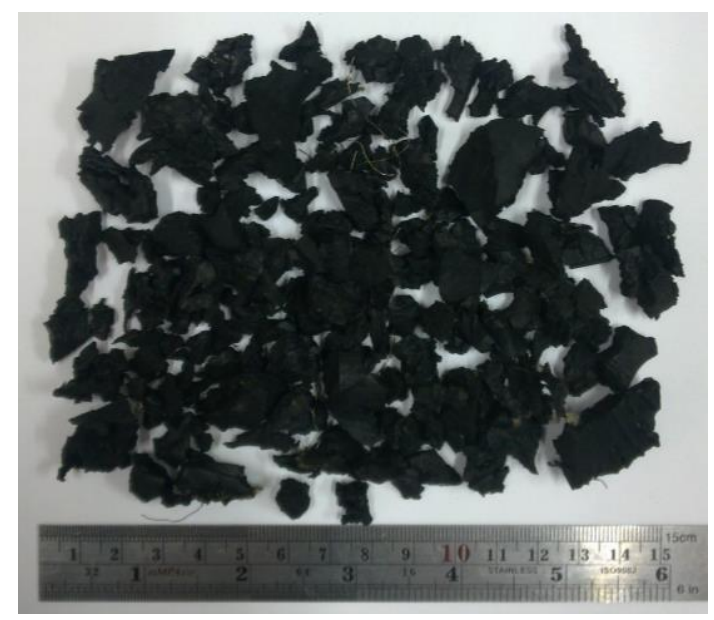

Fig. 2 A view of granulated tire rubber used

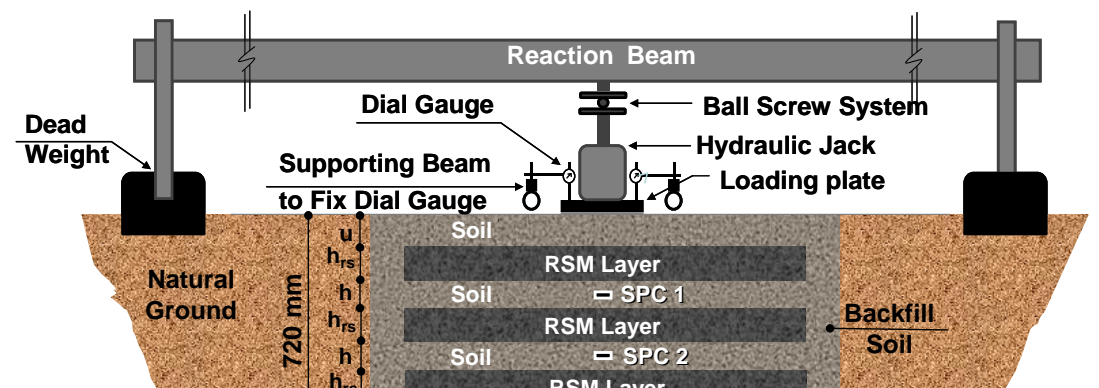


Fig. 3 Schematic cross-section of the test set-up of the foundation bed (Not to scale) containing a model test pit trench, soil and RSM layers, the loading plate model, loading system, dial gauges and soil pressure cells ("SPC 1", "SPC 2", and "SPC 3") inside the foundation bed.

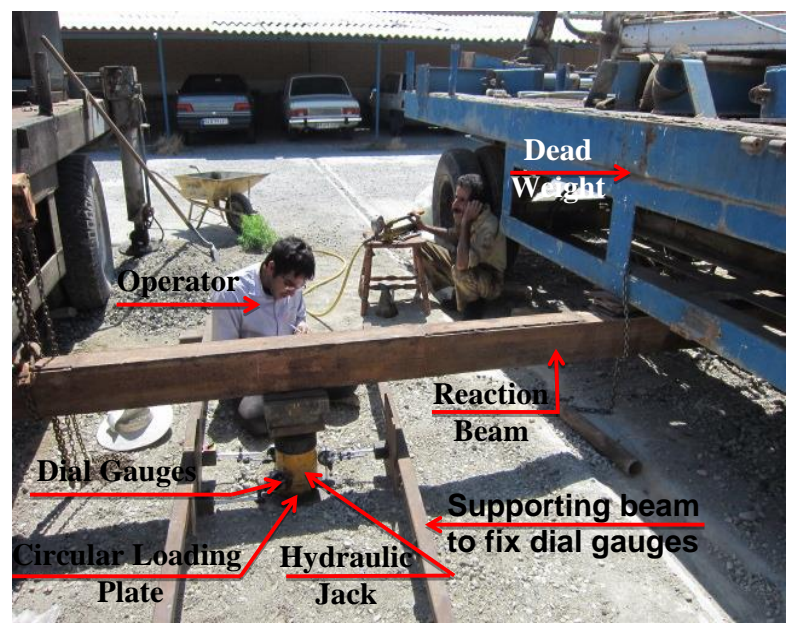

Fig. 4 Photograph of test installation prior to loading include reaction beam, load plate, hydraulic jack and three dial gauges 


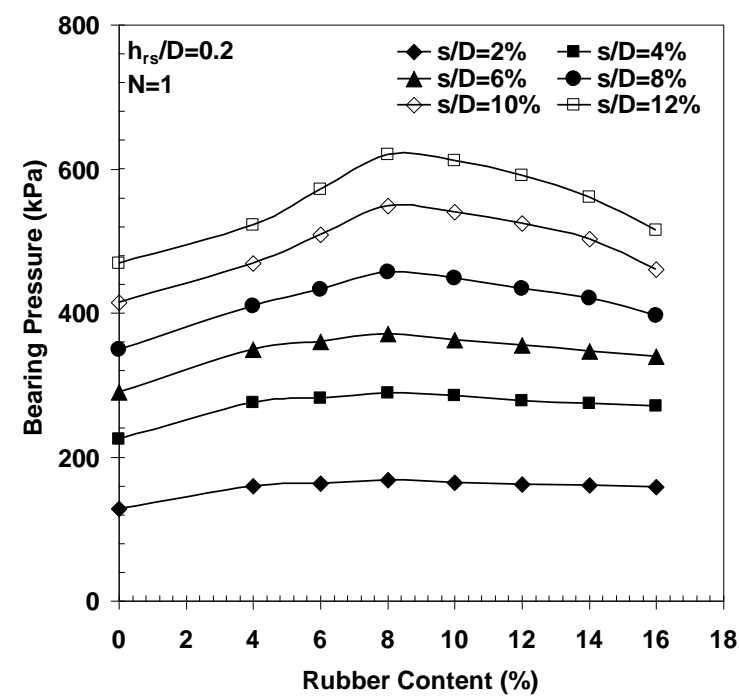

Fig. 5 Variation of bearing pressure with rubber content for one layer of rubber-soil mixture at different values of settlement

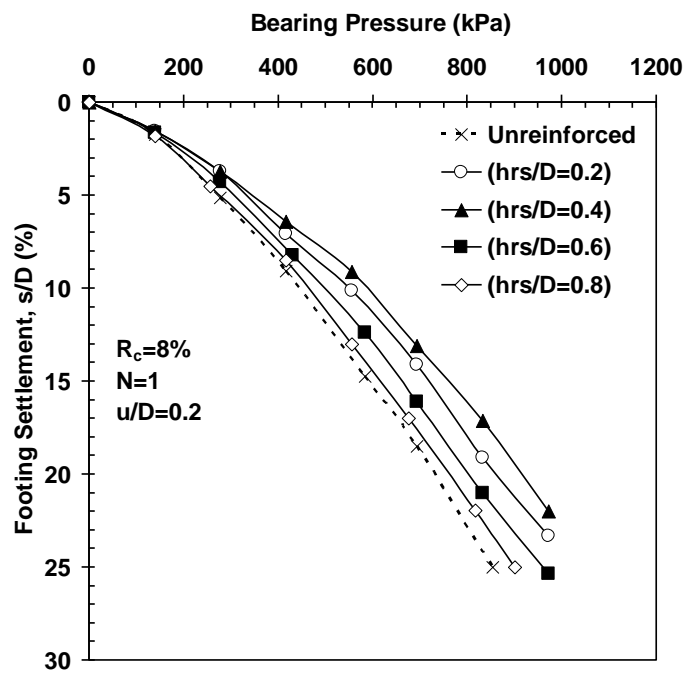

(a) Footing settlement

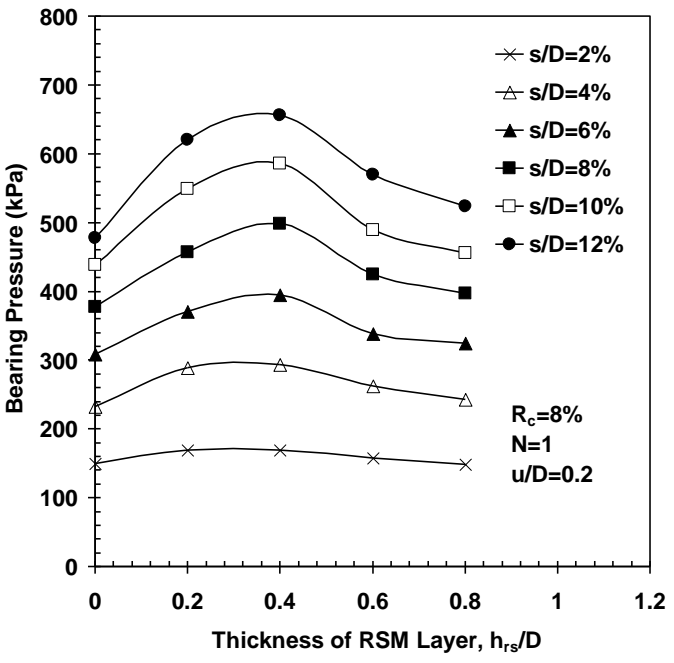

(b) Thickness of RSM layer

Fig. 6. Variation of bearing pressure with footing settlement and with thickness of RSM layer at different footing settlement ratio, $s / D$ 


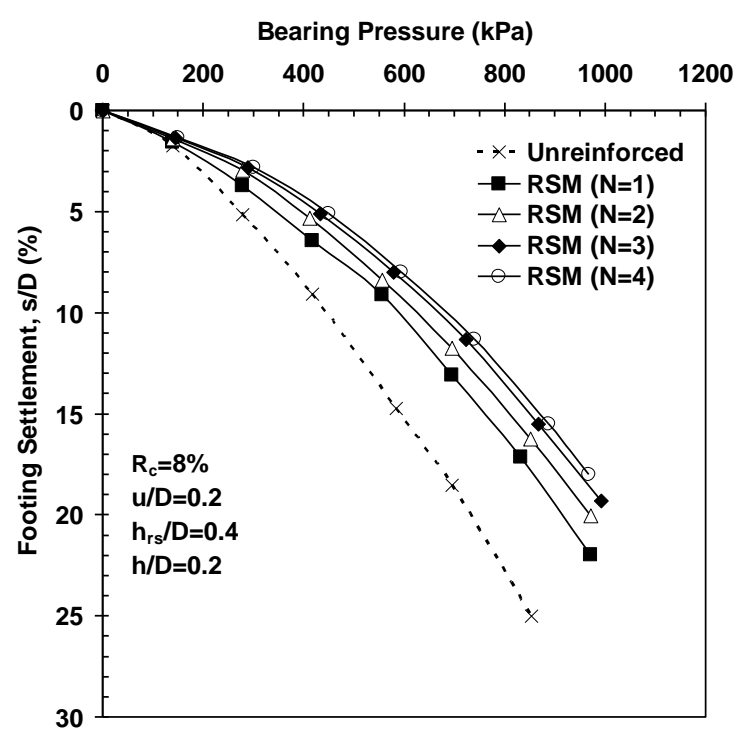

(a) Footing settlement

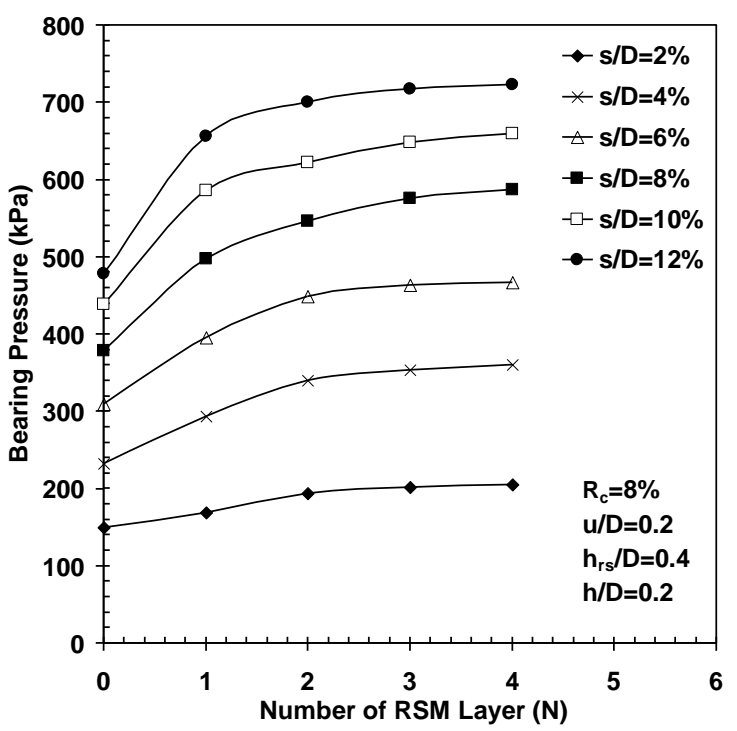

(b) Number of RSM layers at different footing settlement ratio, $\mathrm{s} / \mathrm{D}$

Fig. 7 Variation of bearing pressure with footing settlement and number of RSM layers at different footing settlement ratio, $s / D$

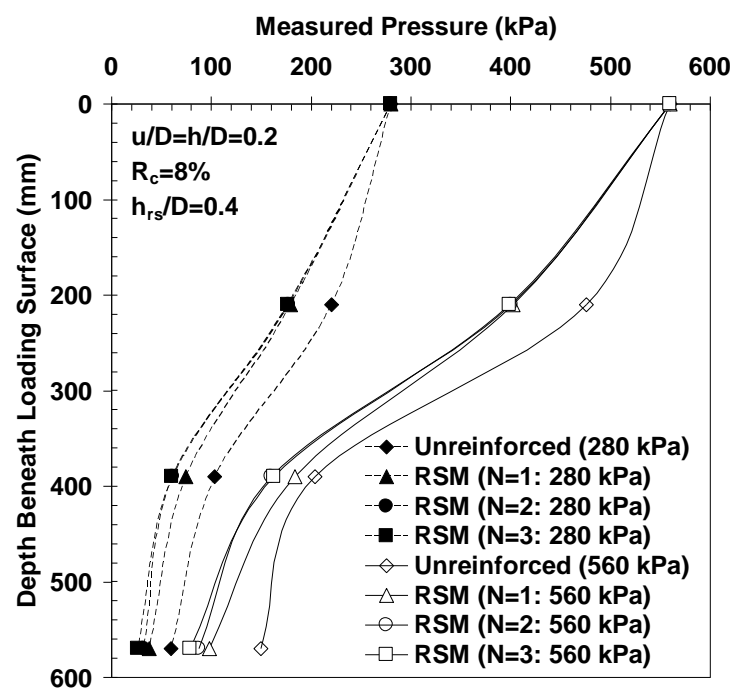

Fig. 8 Variation of measured pressure in depth of unreinforced and RSM beds at applied pressures of 280 and $560 \mathrm{kPa}$ 


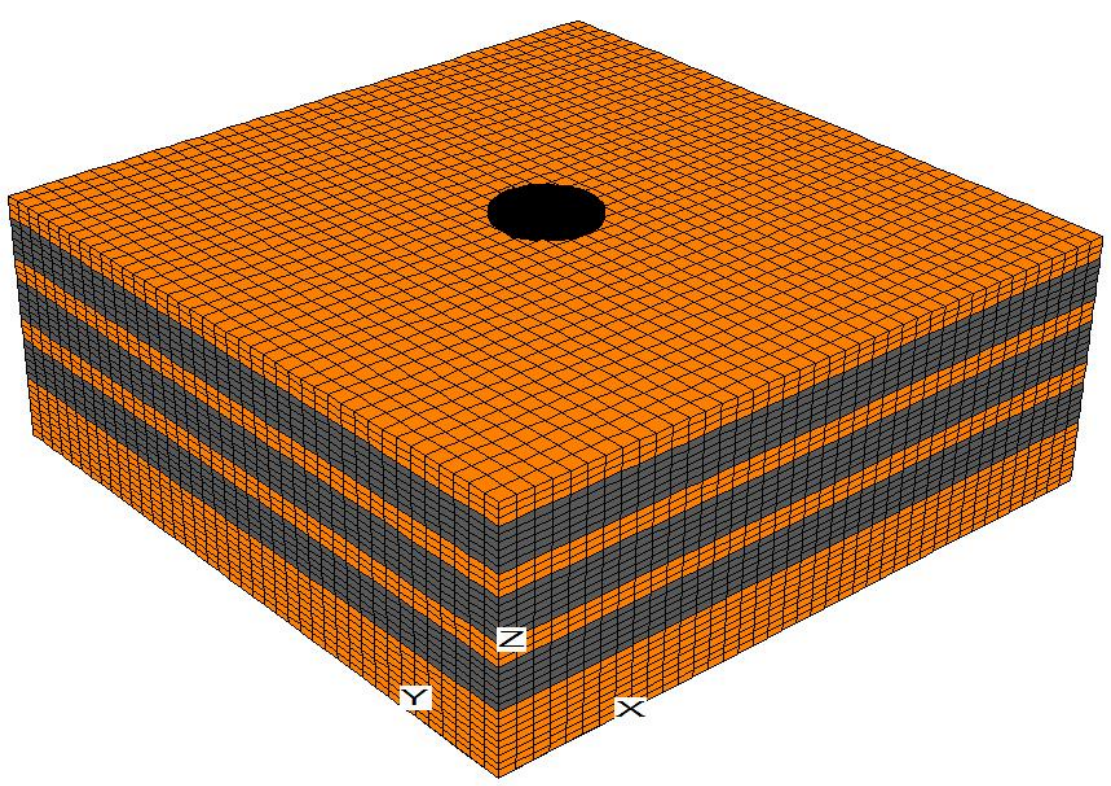

Fig. 9 Meshing area of numerical model for rubber reinforced bed with three layers of RSM and circular surface loading

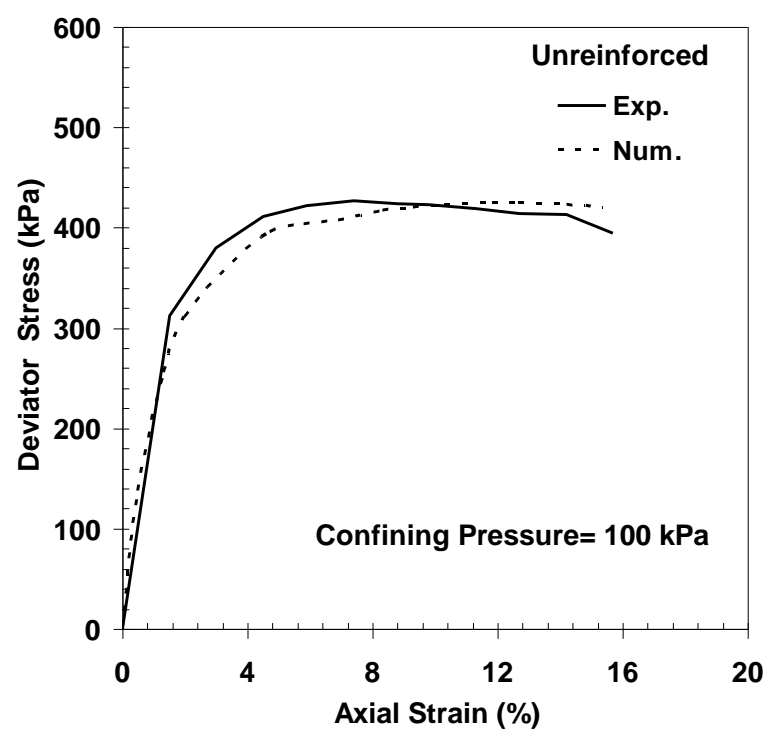

(a) Unreinforced bed

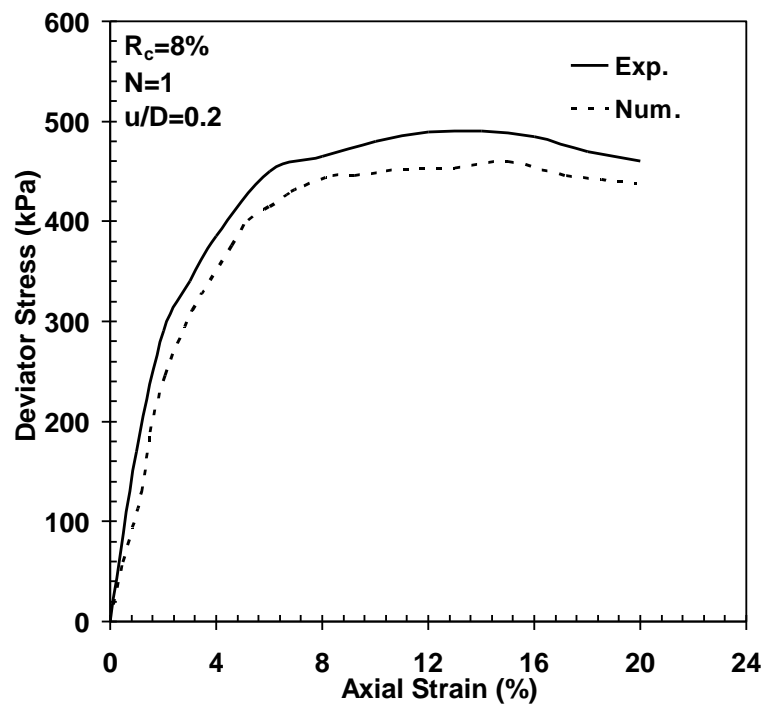

(b) RMS bed

Fig. 10 Comparison between numerical and experimental results at calibration stage 


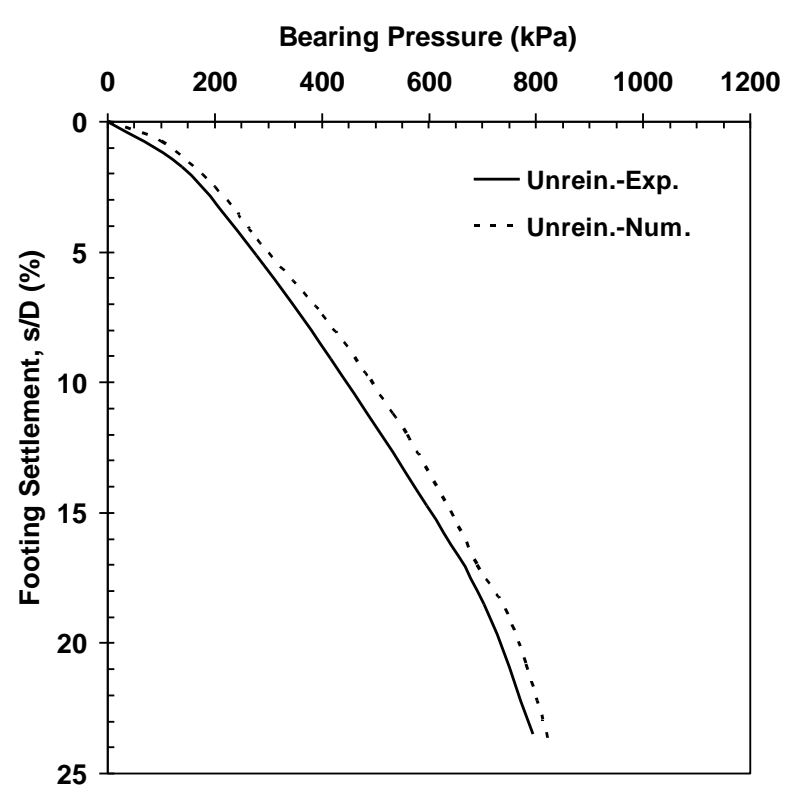

(a) Unreinforced bed $(\mathrm{N}=0)$

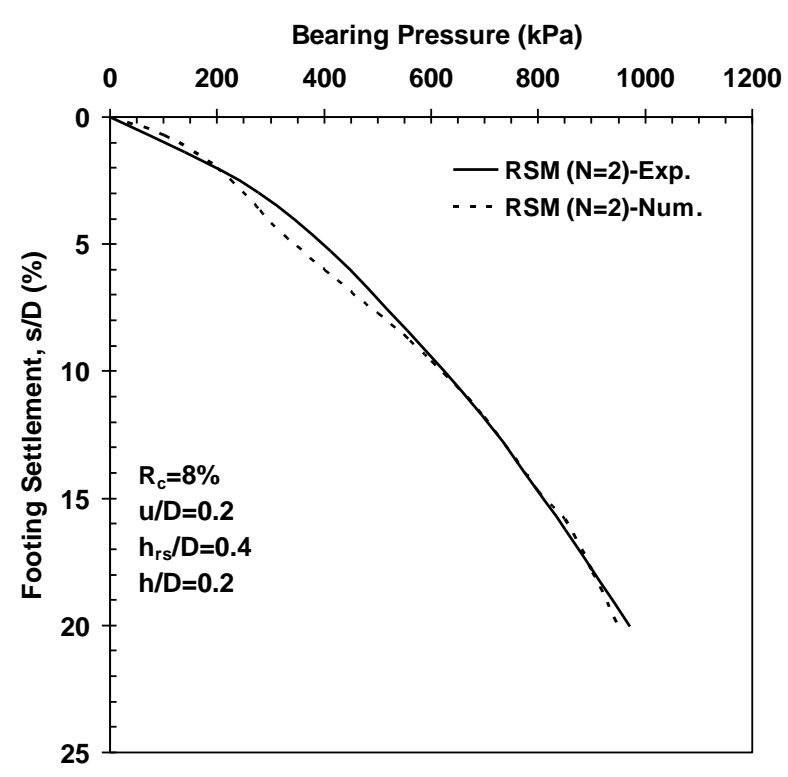

(c) RSM bed $(\mathrm{N}=2)$

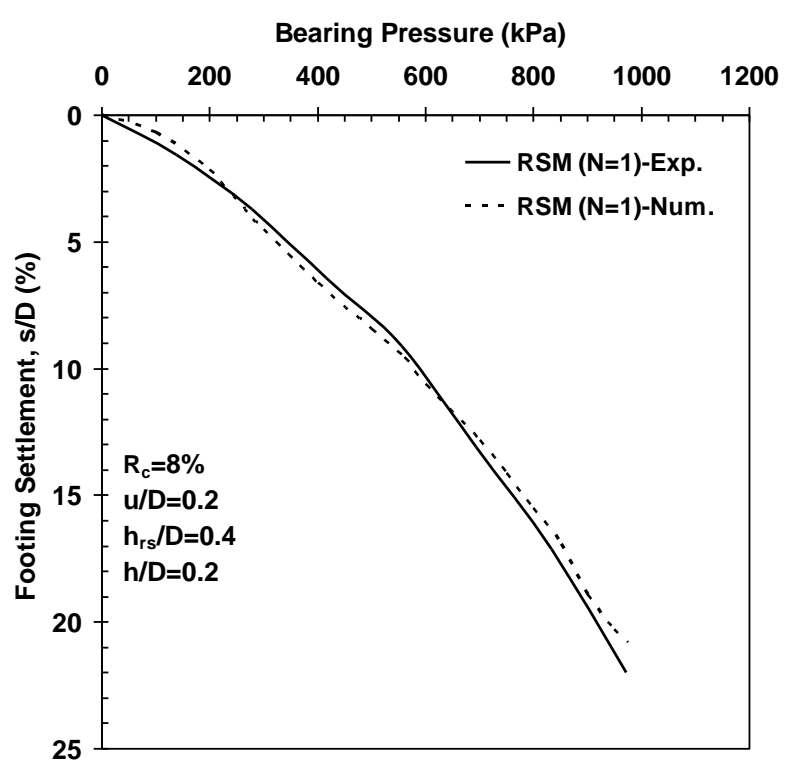

(b) RSM bed $(\mathrm{N}=1)$

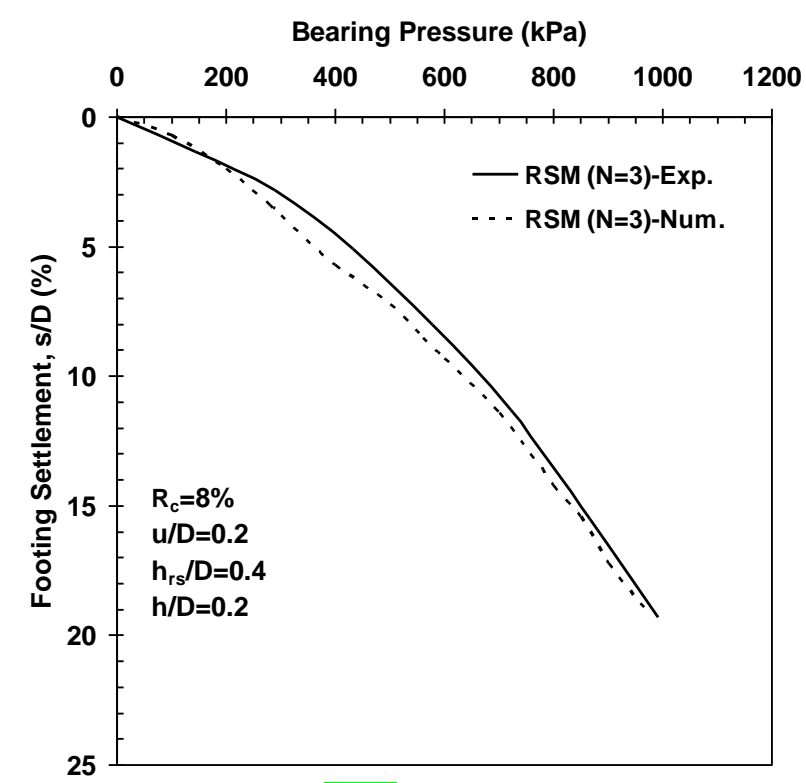

(d) RSM bed $(\mathrm{N}=3)$

Fig. 11 Comparison of pressure-settlement variation obtained from numerical and experimental results for different layers of RSM 


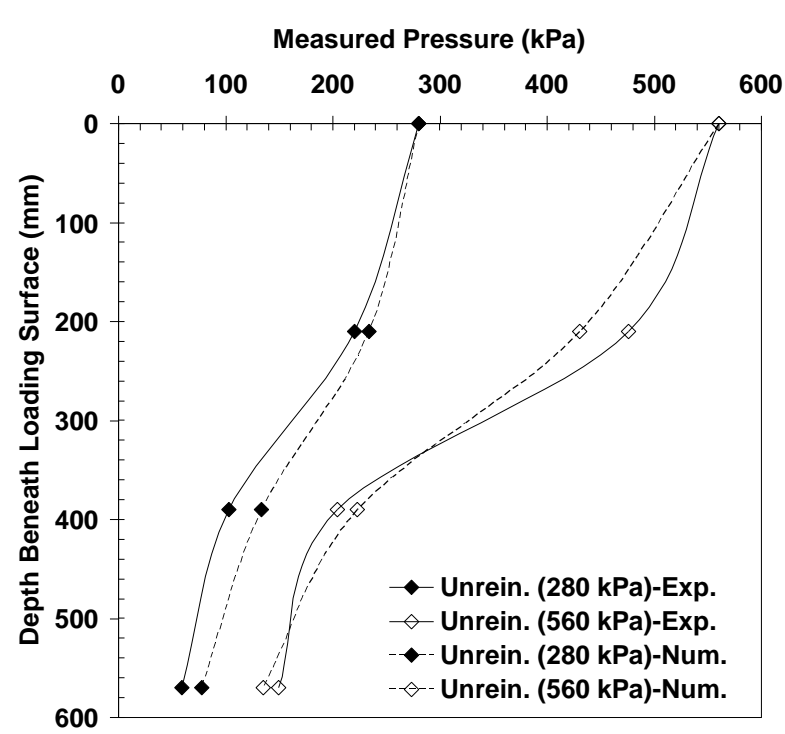

(a) Unreinforced bed $(\mathrm{N}=0)$

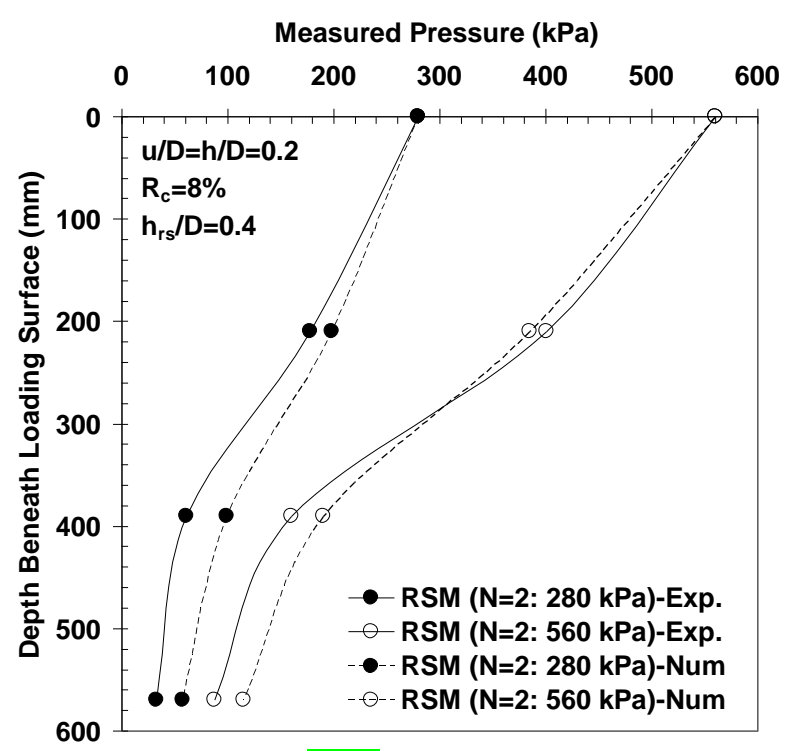

(c) RSM bed $(\mathrm{N}=2)$

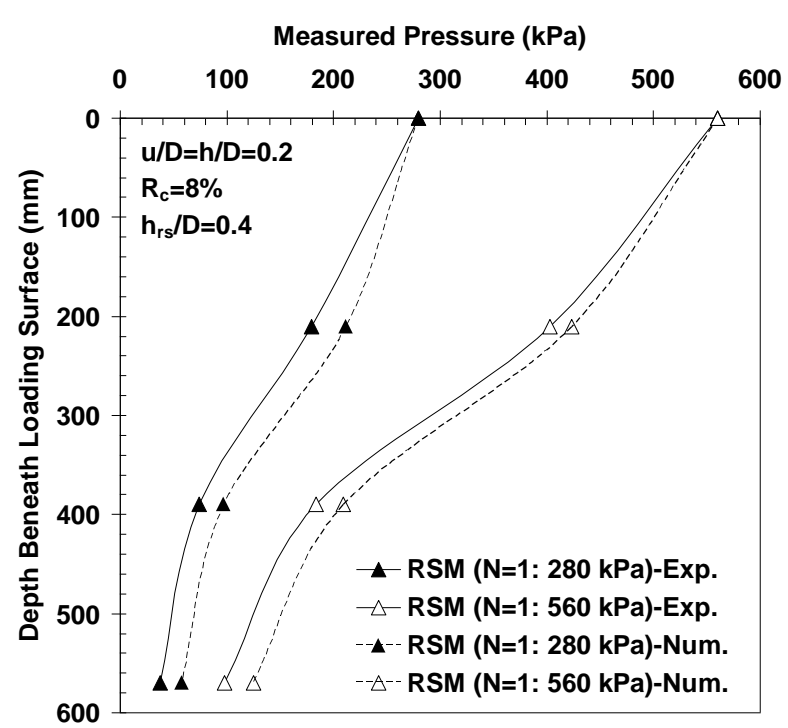

(b) RSM bed $(\mathrm{N}=1)$

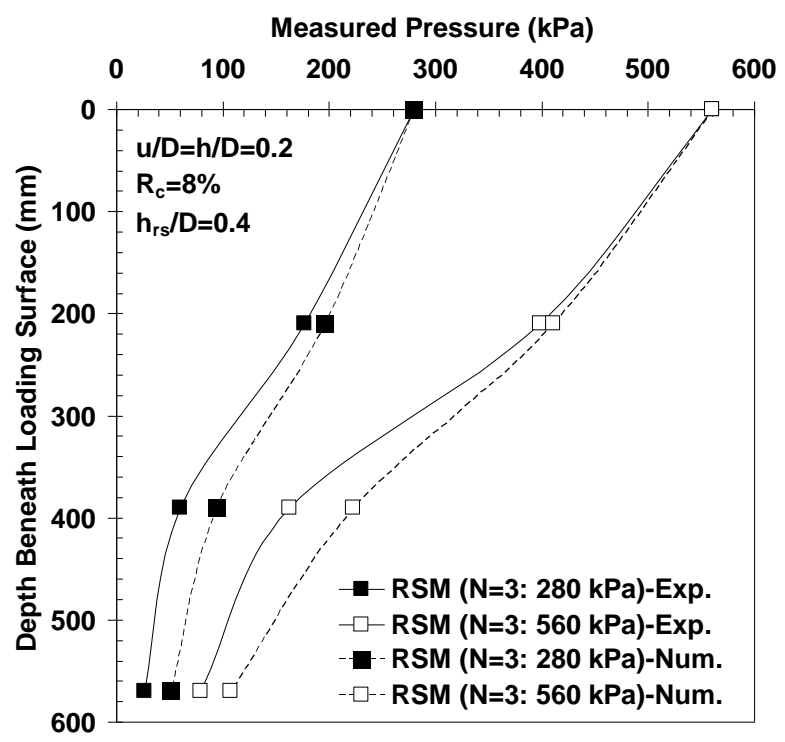

(d) RSM bed $(\mathrm{N}=3)$

Fig. 12 Comparison of measured pressure in depth of foundation beds at applied pressures of 280 and $560 \mathrm{kPa}$, obtained from numerical and experimental results 


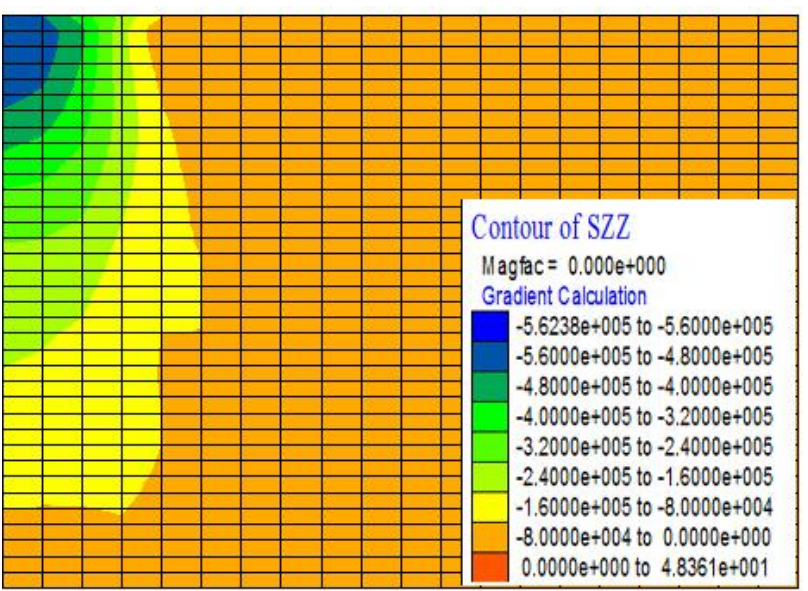

(a) Unreinforced bed $(\mathrm{N}=0)$

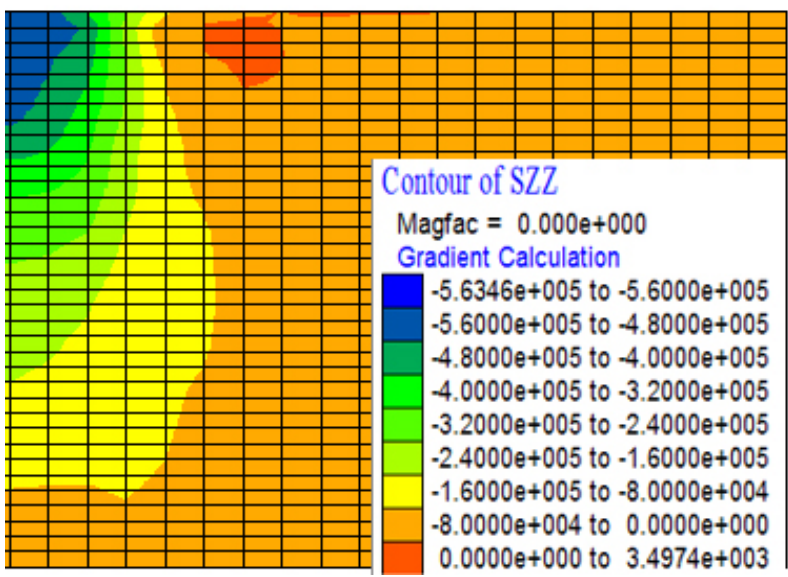

(c) RSM bed $(\mathrm{N}=2)$

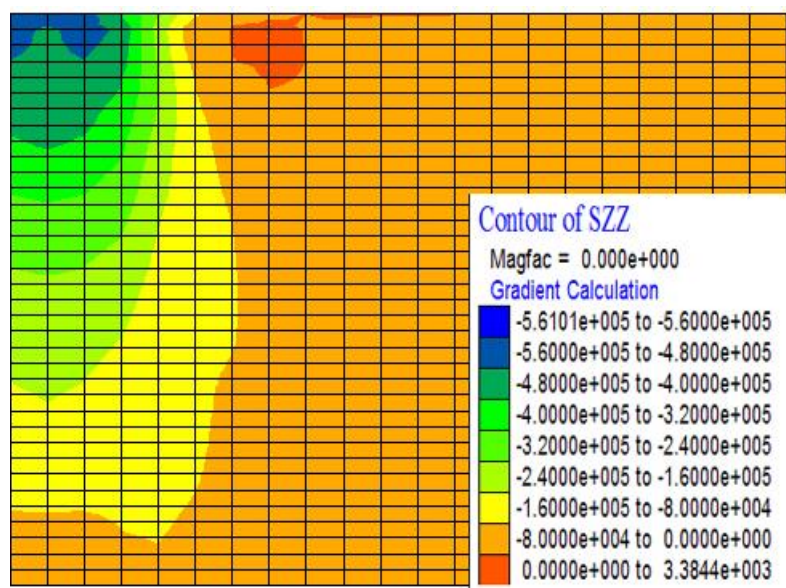

(b) $\mathrm{RSM}$ bed $(\mathrm{N}=1)$

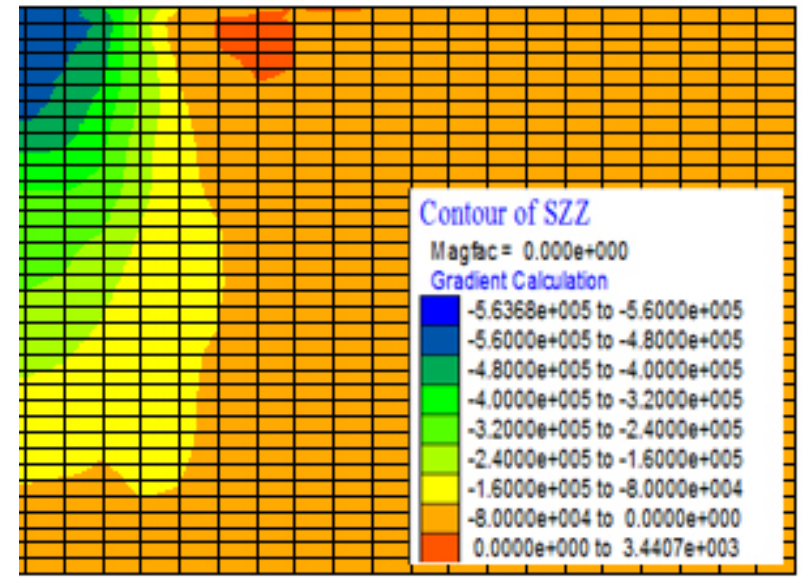

(d) RSM bed $(\mathrm{N}=3)$

Fig. 13 Vertical stress distribution in foundation bed obtained from numerical results 


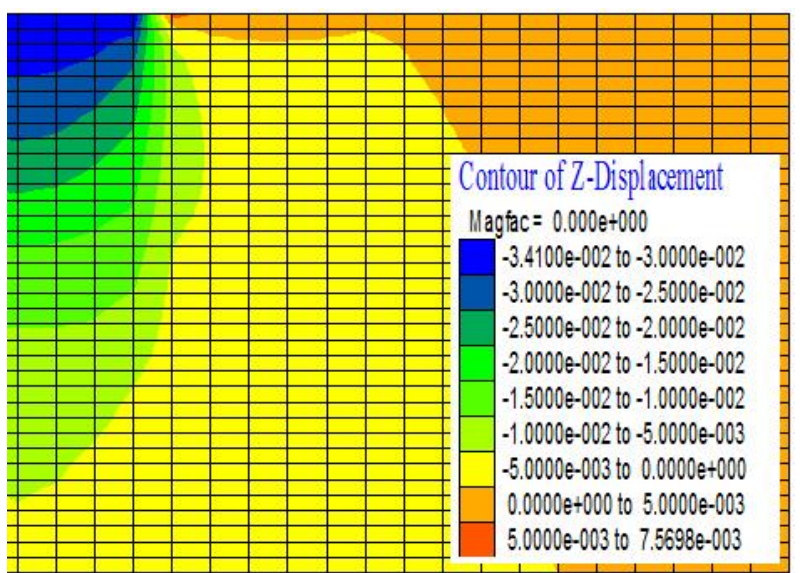

(a) Unreinforced bed $(\mathrm{N}=0)$

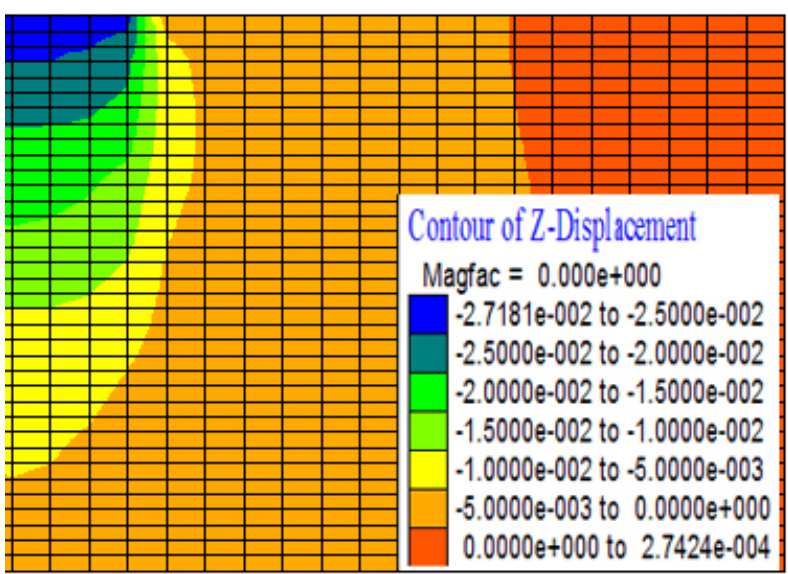

(c) RSM bed $(\mathrm{N}=2)$

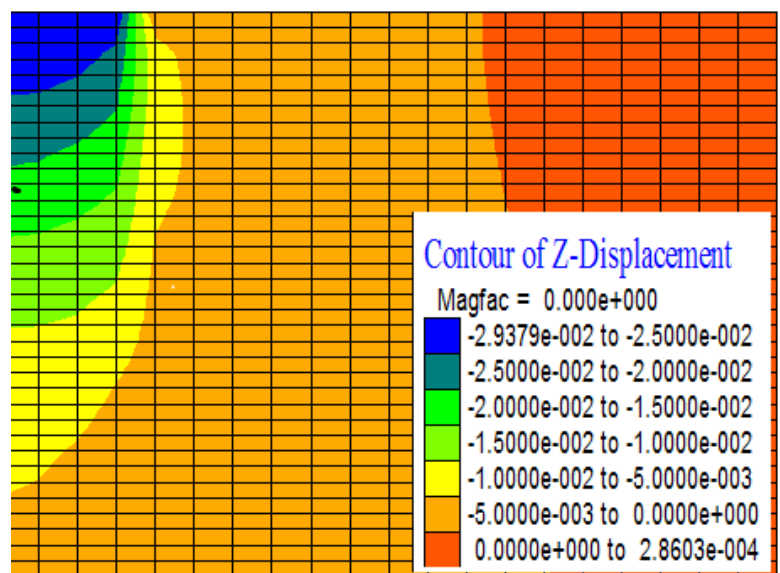

(b) $\mathrm{RSM}$ bed $(\mathrm{N}=1)$

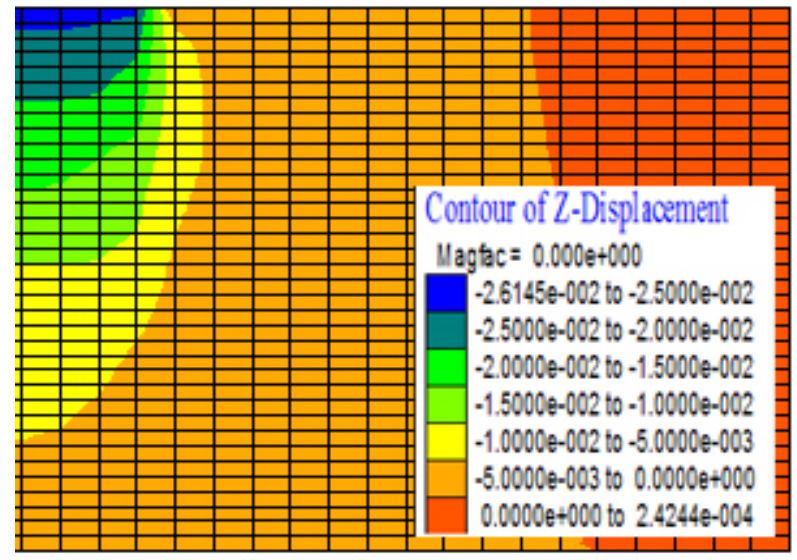

(d) RSM bed $(\mathrm{N}=3)$

Fig. 14 Vertical settlements contours in foundation bed obtained from numerical results 


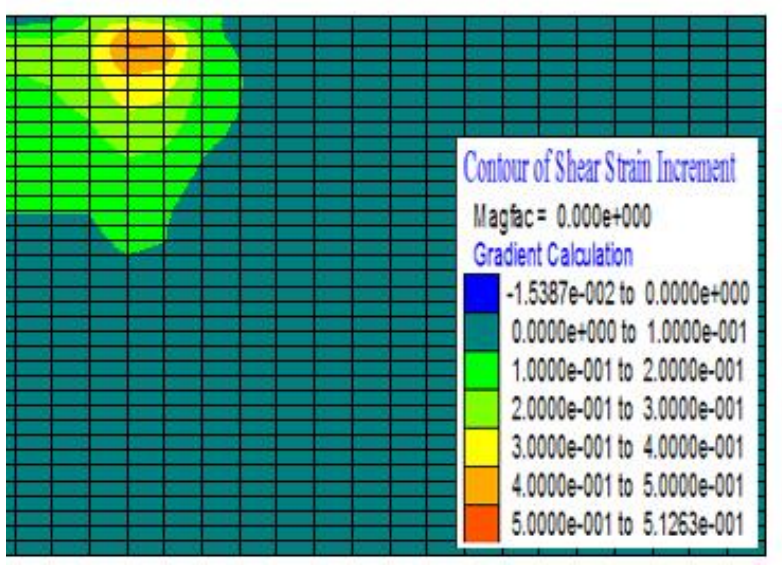

(a) Unreinforced bed $(\mathrm{N}=0)$

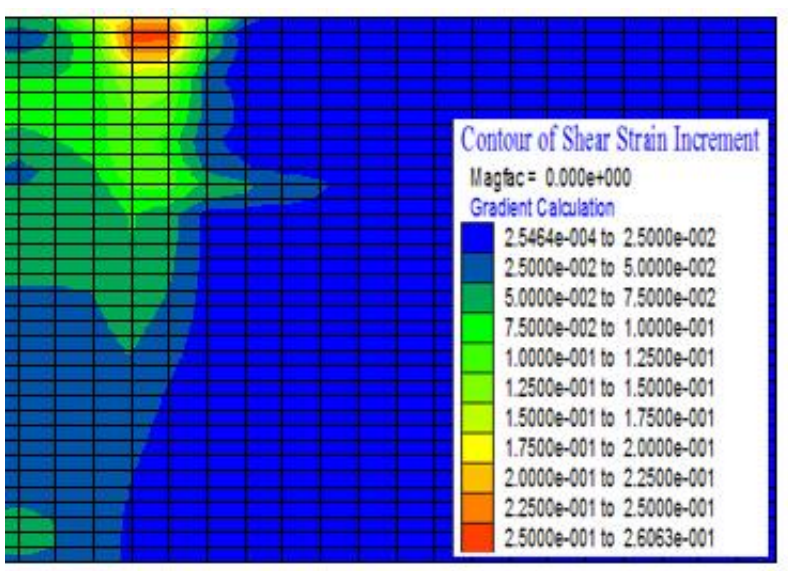

(c) RSM bed (N=2)

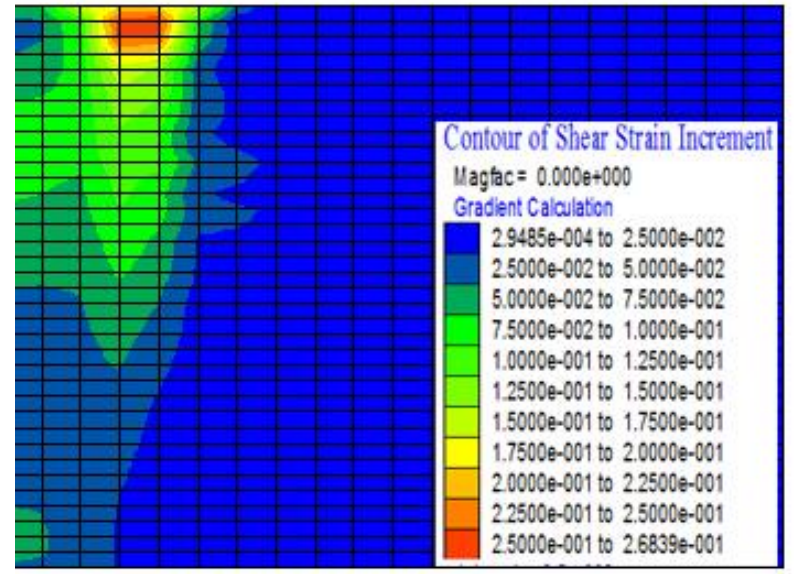

(b) RSM bed $(\mathrm{N}=1)$

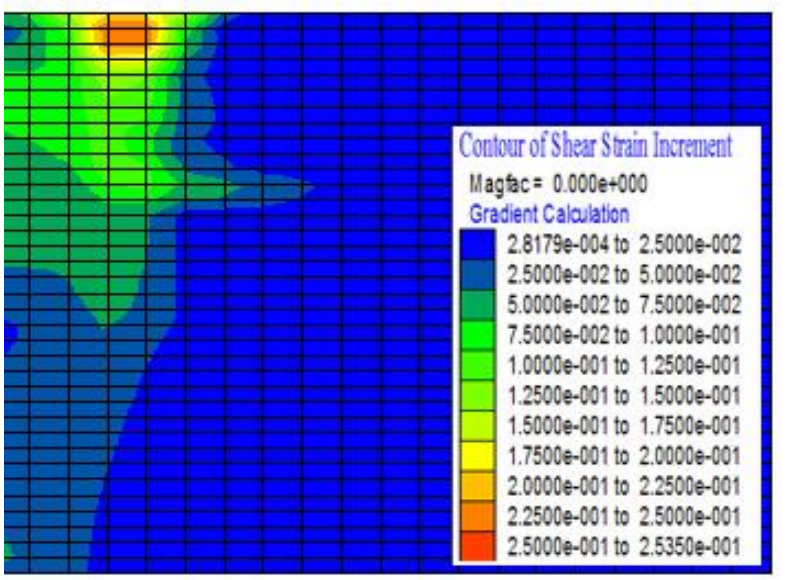

(d) RSM bed (N=3)

Fig. 15 Shear strain contours in foundation bed obtained from numerical results 


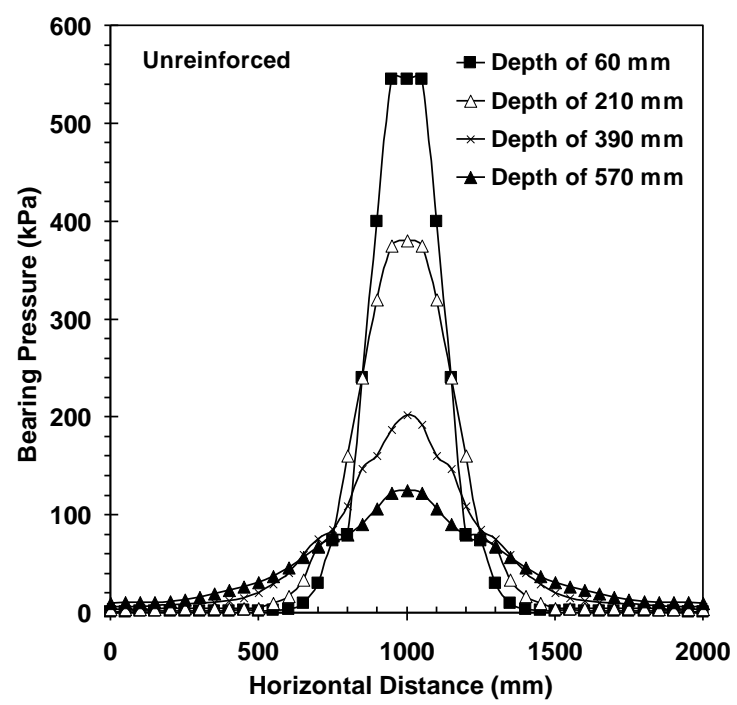

(a) Unreinforced $(\mathrm{N}=0)$

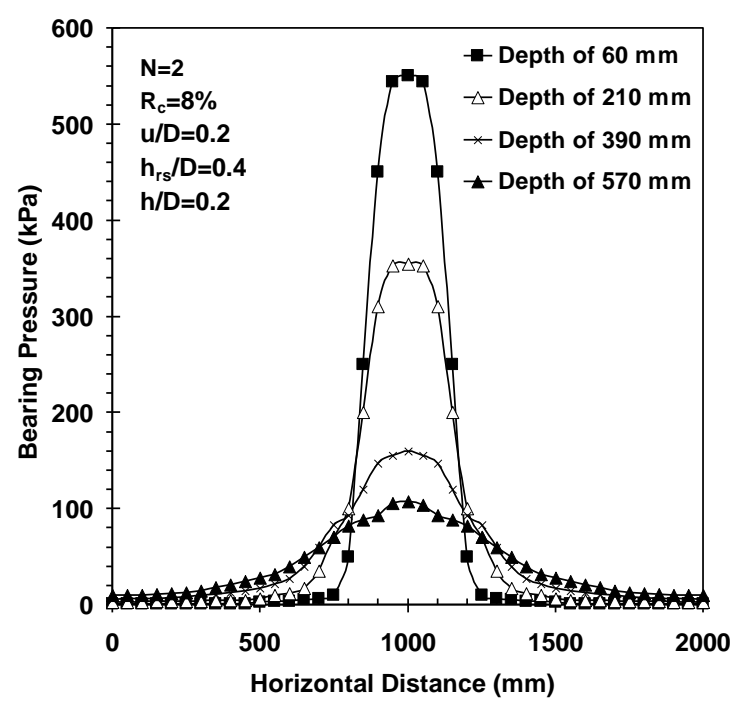

(c) $\operatorname{RSM}(\mathrm{N}=2)$

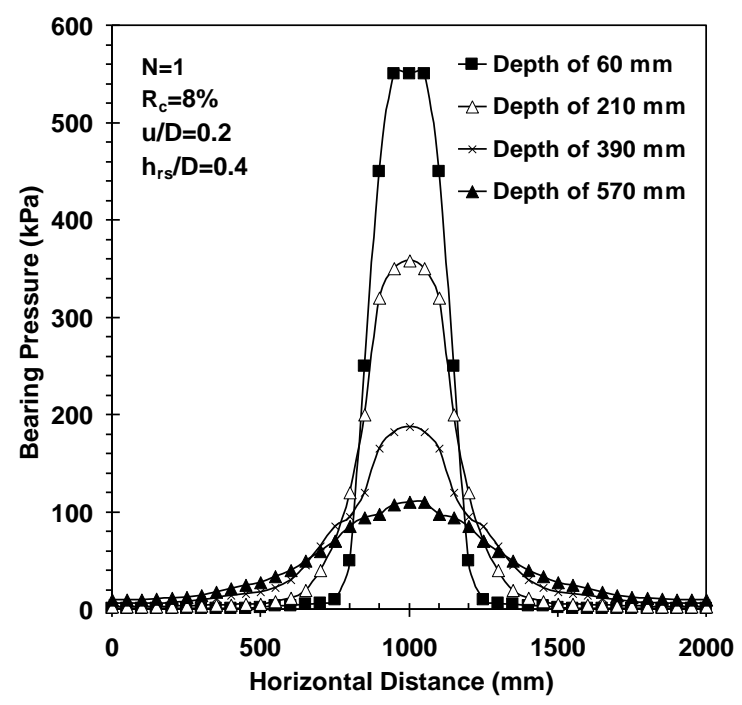

(b) $\operatorname{RSM}(\mathrm{N}=1)$

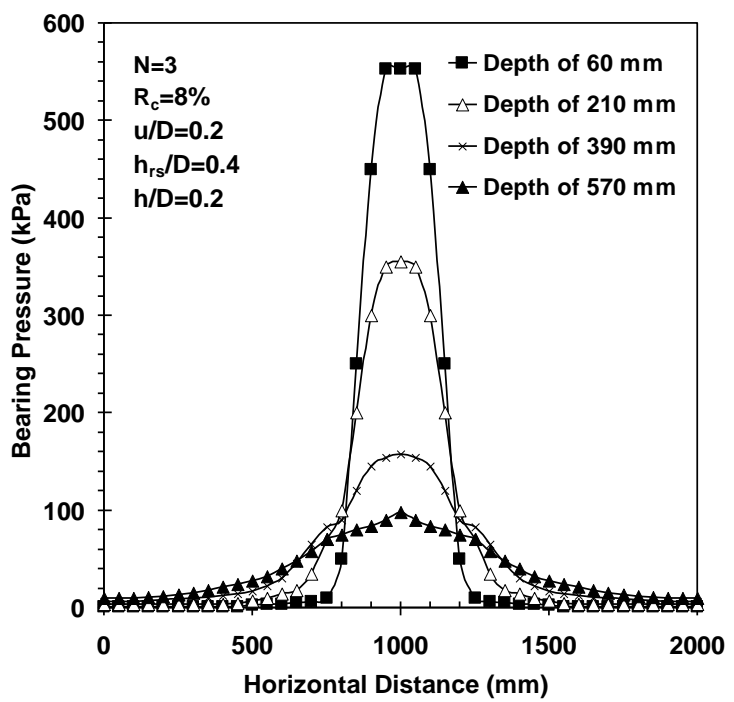

(d) $\operatorname{RSM}(\mathrm{N}=3)$

Fig. 16 Stress distribution for different depth of foundation bed 